\title{
The new release of the database of Earthquake Mechanisms of the Mediterranean Area (EMMA Version 2)
}

\author{
GIANFRANCO VANNUCCI $\left({ }^{1}\right)$ and PAOLO GASPERINI $\left({ }^{2}\right)$ \\ (1) Istituto Nazionale di Geofisica e Vulcanologia, Bologna, Italy \\ $\left(^{2}\right)$ Dipartimento di Fisica, Università degli Studi di Bologna, Italy
}

We present here the second release of a database, running on MS-Access platform, of the earthquake focal mechanisms of the Mediterranean area, published in the literature. For all of the mechanisms (more than 6000) the published parameters, taken from about 193 papers, have been checked for consistency and if necessary corrected when possible. The MS-Access application also allows the major moment tensor catalogs available for the area to be imported (without checking) and used.

\section{INTRODUCTION}

The motivation of this work originates from the difficulties that any investigator interested in seismotectonics and seismic hazard analysis of Italy and surrounding regions encounters when collecting fault plane solutions from the literature. Italy is in fact a region with a relatively moderate seismicity, where earthquakes above the magnitude threshold of the Harvard CMT Catalog (about $M_{w}>5.5$ ) have been only a few dozen since 1976. Therefore the contribution given by first pulse mechanisms published in the literature is also necessary to well characterize the tectonic styles of the various seismic source areas. The difficulties in using such data mainly come from the fact that they were very dispersed over a large number of papers and that, due to the hard copy format, they were not readily available for analyses by computer codes. Moreover, a number of mistakes are occasionally found in some of them, going from the incorrect use of terms (i.e. strike instead of dip-direction) to inconsistencies of the reported data (i.e. non-orthogonality of fault planes and deformation axes, inconsistency between plane and axes, etc.).

Therefore, taking advantage of a call for proposals, within the Framework Project 2000/2002 of the Italian Gruppo Nazionale Difesa dai Terremoti (GNDT), our group submitted a Coordinate Project («Revision of the theoretical and observational grounds of seismic hazard estimates at a national scale») where one of the tasks concerned the development of a reliable catalog of focal mechanisms to be used in new hazard estimates. We thus started to collect focal solution, from the national and international literature. Initially our interest was limited to Italy and the surrounding regions, but later the area was extended to include the whole Mediterranean Sea and surrounding regions, from the Atlantic Ocean to Iran. The first version of the database, published more than a year ago (Vannucci and Gasperini, 2003), contains 4995 mechanisms taken from 177 directly examined papers, some of which refer to 117 other works (mostly thesis or technical reports) which it was not possible to find. Such version was recently used to constrain the tectonic styles of the seismogenic source areas of the new seismic zonation ZS9 (ZS9 Working Group, 2004) which has been developed 
within the framework of the INGV initiative following the Italian Prime Minister's Ordinance of March 20, 2003 for the assessment of the new seismic hazard map of Italy.

The database is embedded in an MS-Access application allowing visual comparison between original and recomputed focal mechanisms data, the importing of the data from the on-line Global CMT Harvard Catalog and from two regional RCMT catalogs (Istituto Nazionale di Geofisica e Vulcanologia - INGV - of Rome and Eidgenössische Technische Hochschule - ETH - of Zurich), the selection of mechanisms on the basis of various criteria and exporting onto ASCII files of the data to be used in further computations.

An added value of the EMMA database is checking all the mechanism parameters for consistency and, in case of problems, correcting them so that the mechanisms are immediately usable for drawing maps or making further computations like the ones shown in the previous article of this issue. We checked that angles between planes and between axes did not differ from $90^{\circ}$ by more than three degrees. Also, we checked the consistency between fault planes and axes and between moment tensor components and planes or axes. To make all of these checks and to homogeneously re-compute all relevant parameters (fault planes and deformation axes angles, moment tensor components) for each mechanism, we developed a structured package of Fortran 77 subroutines (FPSPACK, Gasperini and Vannucci, 2003) performing the most common computations and checks on focal mechanism data. This package is freely available from the ftp server of Computers \& Geosciences journal: ftp://ftp.iamg.org/VOL29/ v29-07-08.zip and includes, among others, routines to compute nodal planes from $P$ - and $T$-axes and vice versa and to compute moment tensor components from planes or axes or best double couple parameters from moment tensor components. All definitions, conventions and formulas we have used are reported in Appendix A.

To make reliable selections on the basis of the earthquake size and to compute the seismic moment tensor, we uniformly computed the scalar seismic moment, using empirical regressions with available magnitude estimates for all of the mechanisms for which this parameter is not reported in the original paper.

Another feature of the EMMA database is the choice of the best mechanism among the available duplicates. We weighted each solution on the basis of a series of objective criteria based on: i) the correctness of the solution (presence or absence of errors in the published FPS parameters); ii) the originality of the source (original sources are preferred with respect to indirect ones); iii) the «authoritativeness» of the source (chosen roughly proportional to the impact factor of the journal where the mechanism is published); iv) the recentness of the publication (most recent papers override previous ones). We did not consider any kind of quality estimators (solution quality factor, number of stations, etc.) as these are only given by a minority of the published solutions. The «best solution» is the one with the highest weight and is marked in the database by a specific flag that can be included in selection.

\section{Database Contents AND FUnCtionalities}

This second version of the database is released about one year after the first one, taking advantage of this Special Issue of Annals of Geophysics to distribute it among the scientific community. All files required to run the MS-Access application are included in a CD-ROM attached to the journal (see EMMA_tutorial.pdf file inside the CD-ROM the instructions to install and use the MS-Access application). The spatial coverage is similar to previous version (see fig. 1) but the consistency of the data was only improved of about $20 \%$ (see table I). The present one is the first release available to a wide community of potential users as the initial release only had a circulation among a restricted ambit. The origin time year ranges from 1905 to 2003 while the moment magnitude $M_{w}$ from 4 to 8.7.

The MS-Access application we have written allows users to access mechanism data through a series of menus and masks (figs. 2 to 5). The user can display the mechanisms of the entire database or make selections on the basis of earthquake source parameters (date, location, magnitude, etc.) and/or 


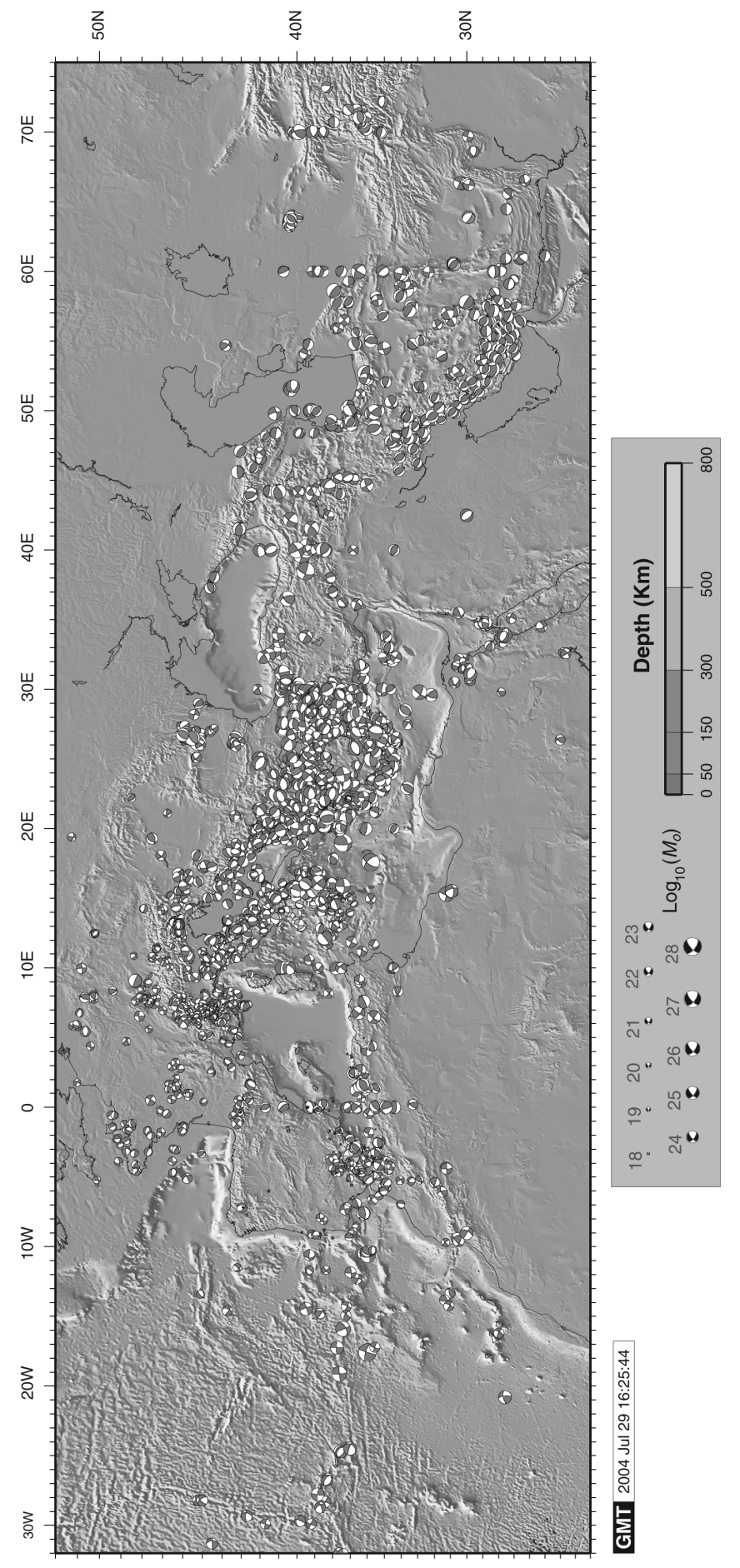

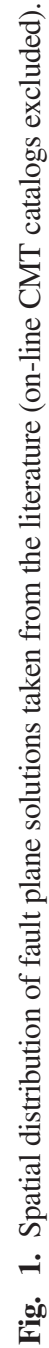


Table I. Summary of the results of the checks performed on the focal mechanisms found in hard copy literature.

\begin{tabular}{lcc}
\hline \hline Type of data & Number & $\%$ \\
\hline All examined & $\mathbf{6 1 5 6}$ & $\mathbf{1 0 0 . 0}$ \\
Correct FPS parameters & 3761 & 61.1 \\
FPS parameters with some defects & 2395 & 38.9 \\
Recoverable & $\mathbf{2 0 9 0}$ & $\mathbf{3 4 . 0}$ \\
Wrong axes, correct planes and rakes & 126 & 2.0 \\
Wrong planes or rakes, correct axes & 1459 & 23.7 \\
Only strike and dip of two planes (polarity determined from figures) & 505 & 8.2 \\
Unrecoverable & $\mathbf{3 0 5}$ & $\mathbf{4 . 9}$ \\
Axes and/or planes not perpendicular & 205 & 3.3 \\
Undetermined & 100 & 1.6 \\
Correct+recovered & $\mathbf{5 8 5 1}$ & $\mathbf{9 5 . 1}$ \\
Lacking of earthquake identification parameters (date, location, magnitude) & 300 & 4.9 \\
Usable solutions & 5551 & 90.2 \\
Duplicate solutions & 2316 & \\
Distinct earthquakes & $\mathbf{3 8 4 0}$ & $\mathbf{1 0 0 . 0}$ \\
Earthquakes with only one mechanism & 2906 & 75.7 \\
Earthquakes with more than one mechanism & 934 & 24.3 \\
\hline
\end{tabular}

of bibliographic references (authors, journal, etc.). In addition, the mechanism data can be exported to ASCII files to be plotted by GMT (Wessel and Smith, 1991), or processed by external codes. Another feature of the MS-Access application is the compilation and export of the list of bibliographic references of all of the data or a selection of them. This simplifies the correct citation of all of the contributing papers to investigations making use of the EMMA database. We will give here only an overview of the main features of the MS-Access application while a more complete description can be found in the EMMA_tutorial.pdf file inside the CD-ROM.

At the startup, the MS-Access application shows the Main menu with four choices (fig. 2): the first (EVENT SELECTION) allows users to access an Event Selection Mask (fig. 5), the second (COMPLETE DATABASE) accesses a further menu allowing to display (fig. 3), view and export the complete reference list, export onto ASCII files the focal mechanism data, the third (IMPORT CATALOGS) accesses a menu allowing users to import in the database the focal solutions data of three on-line catalogs:

- The global CMT Catalog continuously updated by the Harvard Seismology team (Dziewonski et al., 1981 and subsequent papers appeared quarterly in Physics of the Earth and Planetary Interiors) is available at: http://www.seismology.harvard.edu/projects/CMT/.

- The Regional CMT (RCMT) Catalog of the Mediterranean Region, published by the Istituto Nazionale di Geofisica e Vulcanologia (INGV) of Rome (Pondrelli et al., 2002, 2004), is available at: http://www.ingv.it/seismoglo/RCMT/.

- The Regional CMT (RCMT) Catalog of the Eidgenössische Technische Hochschule (ETH) of Zürich (Braunmiller et al., 2002), mainly covering the Mediterranean region, is available at: http://seismo.ethz.ch/info/mt.html.

The last choice of the Main menu (EXIT) exits the database application.

The Mechanism display window (fig. 3) is accessed from the Main menu as well as from the Event Selection Mask described below. It scrolls the mechanisms by the arrow buttons located close to the bottom-left corner of the window. The two large buttons located close to the arrows activate the Summary and plot window (fig. 4) including a beach-ball plot of the mechanism in the lower hemisphere standard representation and in the upper hemisphere alternative representation 


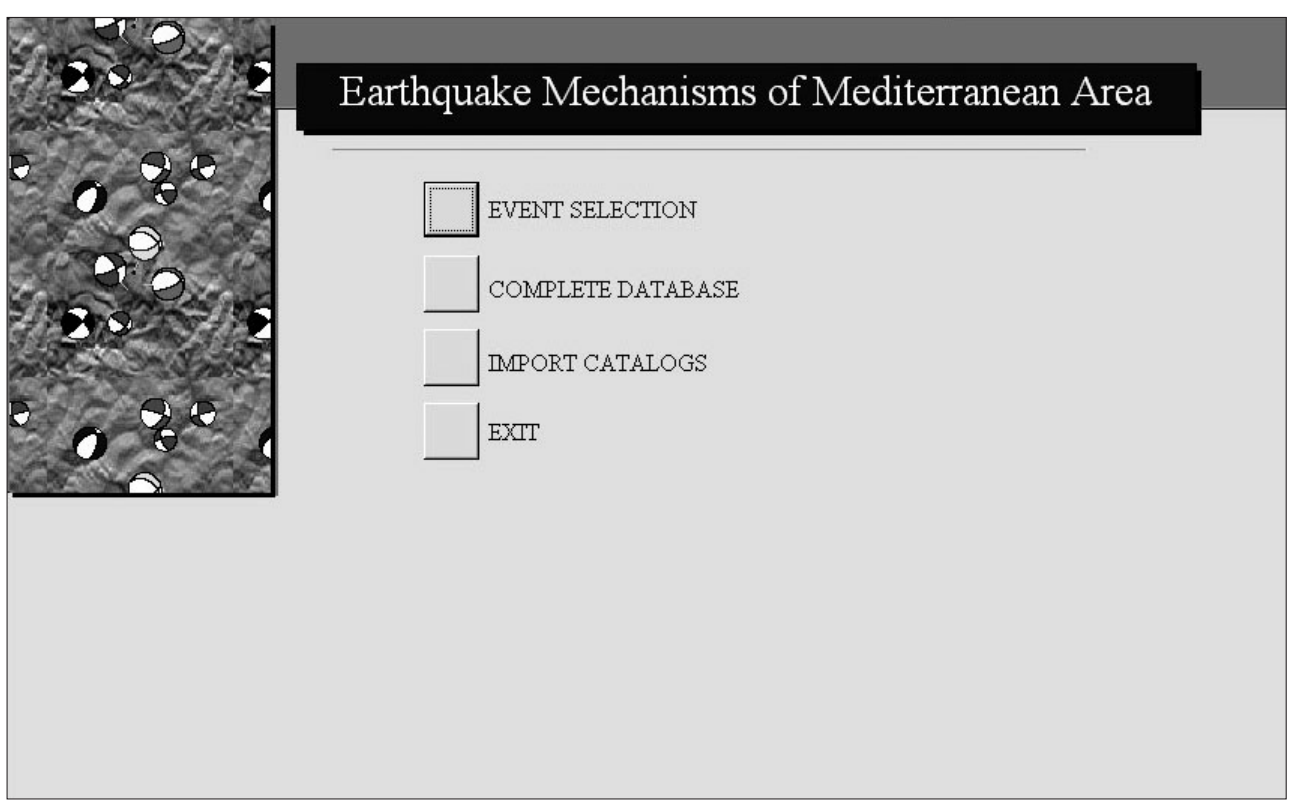

Fig. 2. Main menu of EMMA database.

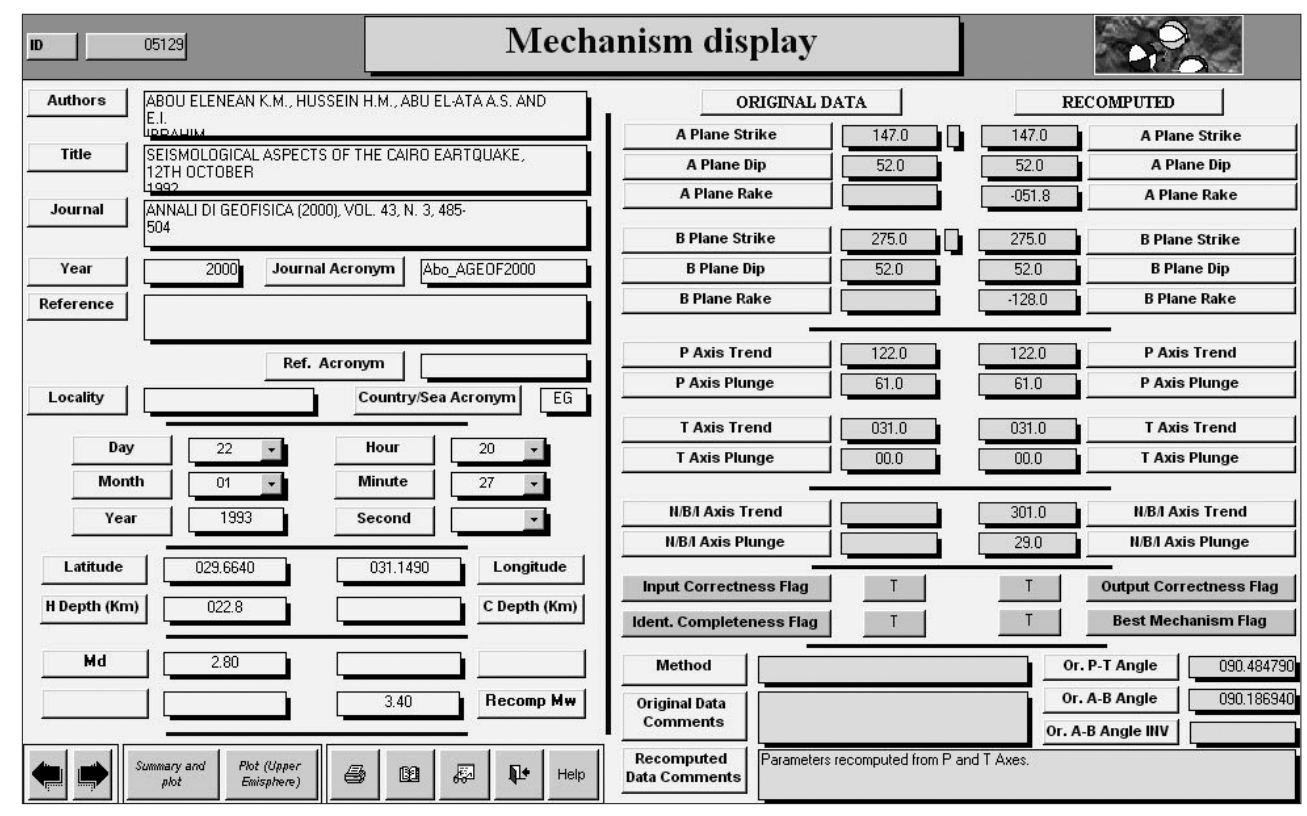

Fig. 3. Mechanism display window. 


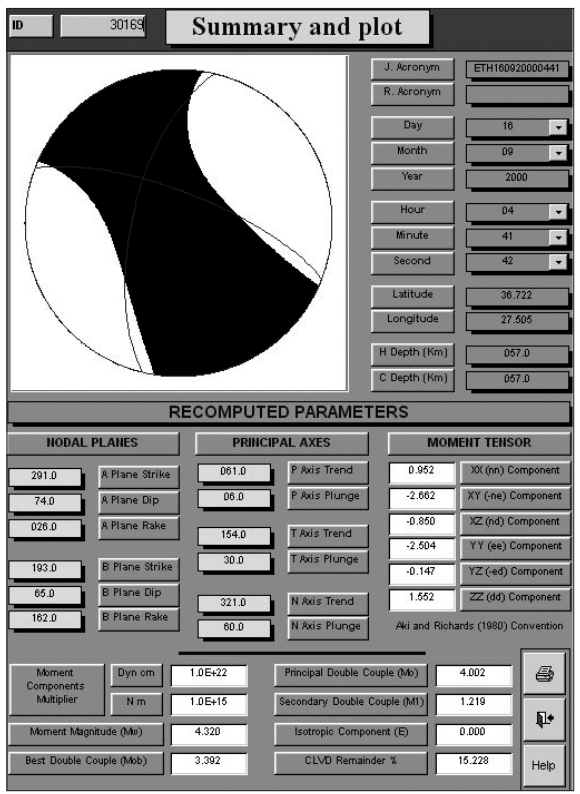

Fig. 4. Summary and plot window (lines indicate best double couple nodal planes).

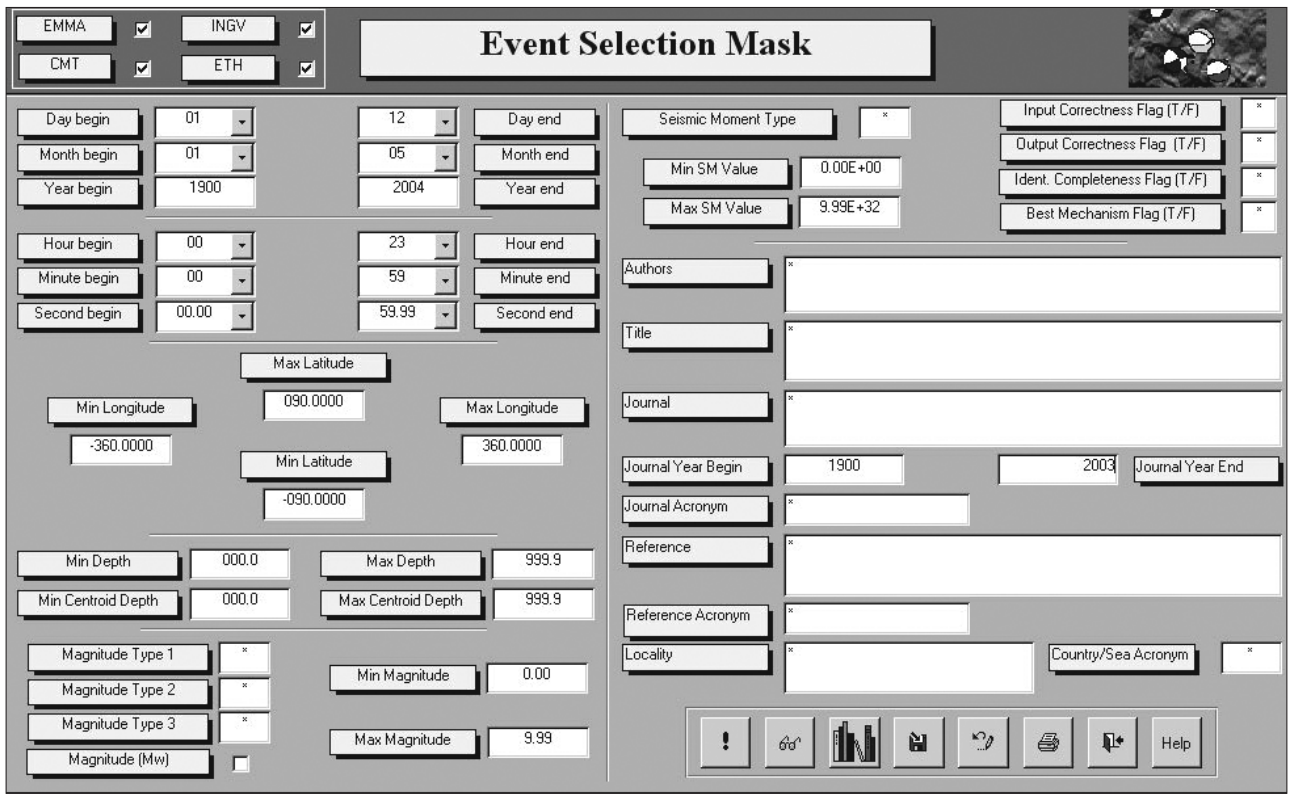

Fig. 5. Mechanism Selection Mask. 
respectively. The remaining buttons, allow users to: print the layout of the window for the current record as well as for all the selected records, activate a window showing the values of additional parameters like moment tensor components and moment tensor decomposition parameters, exit the window and return to the calling menu or mask, display a help window with a brief explanation of each button.

The left-hand side of the mask displays, for each fault plane solution, a comprehensive report of the earthquake parameters and of the bibliography of the work from which the data are actually taken as well as of the original reference, when the latter is not directly available and the data were taken from a paper referring it. All earthquake parameters shown in this section exactly match those reported in the examined source works, excluding the «Recomp. $\mathbf{M}_{\mathrm{w}} »$ moment magnitude. This value is uniformly revaluated from the scalar seismic moment or the magnitudes given by the source, to make uniform magnitude selections and determine the seismic moment tensor. It is the result of different possible choices, depending on the parameters available from the source paper. The highest priority is given to direct $M_{w}$ estimates or ones derived from the reported scalar seismic moment, while in the absence of them, $M_{w}$ is recomputed from other types of magnitude (for details see: Vannucci and Gasperini, 2003). Correspondingly, the scalar seismic moment is recomputed, when not available from the paper, from $M_{w}$ or other types of magnitude.

The right-hand side of the display window reports fault planes and/or deformation axes parameters found on the examined source (ORIGINAL DATA) as well as those (RECOMPUTED) resulting from the validation and correction procedure described by Vannucci and Gasperini (2003). The other information displayed in this side of the window gives details on the mechanism estimate method, on the «correctness» of the original data and, in case of problems, on the procedure followed to correct them. In particular, four logical flags (with only two possible values: true and false) indicate the following focal mechanism properties:

- Input correctness flag: if true, the original nodal planes and/or $P$ - and $T$-axes were found to be consistent among each other and thus no corrections were made to the original data. In this case only the parameters not given by the source are recomputed. If false, some kind of inconsistency was found and then, if possible, all the parameters were recomputed consistently.

- Ident. completeness flag: if true all information needed for an univocal identification of the earthquake (epicentral location, origin-time and magnitude or scalar moment) are available from the source. If false, the data reported by the source do not permit the correct identification and thus the mechanism is not «usable» for further analyses.

- Output correctness flag: if true, the original or the recomputed nodal planes and $P$ - and $T$-axes parameters are correct and usable. If false, the data reported by the source are not consistent and/or do not allow to re-compute reliable parameters. Even in this case the mechanism is not «usable» for further analyses.

- Best mechanism flag: if true, this mechanism is the «best» (in the sense described by Vannucci and Gasperini, 2003) among duplicates for the same earthquake. If false, the mechanism is an alternative solution among duplicates for the same earthquake but not the preferred one.

The boxes located in the lower-right portion of the window report further details on the methods employed to compute the mechanism (First motion, CMT, $P$ - and $S$-waves, velocity models etc.), evident misprints or terms misused in the original data, inconsistencies in the input data (the angles between $P$ - and $T$-axes, and between nodal planes (A and B), and, for defective solutions, a synthetic description of problems encountered with the original mechanism data and the procedure followed to solve them and to re-compute consistent parameters.

The Mechanism selection mask (fig. 5), accessed by the Main menu shows at the top-left corner, the catalog (or catalogs) to be processed. These can be included or not by selecting the tick box corresponding to the different catalogs: EMMA for the revised mechanisms taken from the literature, CMT for the Harvard CMT Project Catalog, ETH and INGV for the Regional MT catalogs of the ETH and INGV respectively. 
The Event Selection Mask generates a database query that always checks only the earthquake date, location and depths and the Journal Year. The remaining parameters are considered for selections only if explicitly selected. The initial limits are set so that to select all the events of the chosen catalogs. The various buttons located in the bottom-right side of the mask allow users to (from left to right): execute the selection, enter the Mechanism display window (see above, fig. 3) allowing to display the selected mechanisms, view or export a list of references, view and export the selected mechanisms data for various purposes, restore the initial settings of the mask, print the layout of mask, exit the mask and return to previous menu, display a help window containing a brief description of the function of each button.

\section{Concluding Remarks}

Although we did our best, we can easily predict that at least some defects are still present in our work. In addition, we certainly missed some published papers (see the complete list of contributing papers in Appendixes I and II). So we explicitly request the collaboration of all investigators interested in improving this database to point out any mistakes and malfunctioning of the procedure they find or the omission of interesting papers they know have been published.

We also want to state clearly that our contribution only represents an added value to the work done by the authors of original papers and thus the database must not be cited as the source of data alone but only as a tool to access them easily. We thus strongly recommend that users insert in their references the complete list of original works that actually computed the focal plane solutions they use. As noted above, a specific option is available to simplify this task in our MS-Access application.

ApPENDIX A. Definitions, conventions and formulas used to check and re-compute mechanism parameters.

The focal mechanism of an earthquake can be completely represented by the seismic moment (symmetric) tensor $M_{i j}$. For a pure double couple it can be defined, in the Aki and Richards System (AR System), as a function of the outward normal and slip vectors of one of the nodal planes as

$$
M_{i j}^{\mathrm{AR}}=M_{0}\left\|\begin{array}{ccc}
2 n_{x} d_{x} & n_{x} d_{y}+n_{y} d_{x} & n_{x} d_{z}+n_{z} d_{x} \\
n_{y} d_{x}+n_{x} d_{y} & 2 n_{y} d_{y} & n_{y} d_{z}+n_{z} d_{y} \\
n_{z} d_{x}+n_{x} d_{z} & n_{z} d_{y}+n_{y} d_{z} & 2 n_{z} d_{z}
\end{array}\right\| .
$$

In this case only four components are independent, while for a general composite mechanism there are six independent components of the moment tensor.

Most of CMT solutions available in the on-line catalogs are given in the Harvard CMT coordinate system. The tensor can be expressed as a function of the six independent components reported on the CMT Catalog $\left(M_{S S}, M_{E E}, M_{R R}, M_{S E}, M_{R S}, M_{R E}\right)$ as

$$
M_{i j}^{\text {Harvard }}=M_{0}\left\|\begin{array}{lll}
M_{S S} & M_{S E} & M_{R S} \\
M_{S E} & M_{E E} & M_{R E} \\
M_{R S} & M_{R E} & M_{R R}
\end{array}\right\|
$$


As the direction of two coordinate axes (1 and 3) are reversed with respect to the AR System, the signs of the components 1-2 and 2-3 must be exchanged when passing from one to the other of the two systems

$$
\begin{aligned}
& M_{12}^{\mathrm{AR}}=M_{21}^{\mathrm{AR}}=-M_{12}^{\text {Harvard }}=-M_{21}^{\text {Harvard }} \\
& M_{23}^{\mathrm{AR}}=M_{32}^{\mathrm{AR}}=-M_{23}^{\text {Harvard }}=-M_{32}^{\text {Harvard }} .
\end{aligned}
$$

The eigenvectors of the moment tensor corresponding to the most negative, most positive and intermediate eigenvalues coincide with the directions of the $P_{-}, T$ - and $B$-axes. Hence these can be used to compute the nodal planes of the double couple best representing the mechanism. The latter however well represents the entire mechanism only when the most compressive and most tensional eigenvalues are close in modulus and the intermediate one is negligible with respect to them. Otherwise the mechanism is complex and can be decomposed making some assumptions on the causative mechanics (see i.e. Lay and Wallace, 1995; and Julian et al., 1998, for a comprehensive discussion of different cases).

All decomposition methods require the removal of the isotropic tensor component. The result of this operation (preliminarily done in most CMT catalogs) is the deviatoric moment tensor that in the major axis coordinate system is given by

$$
\left\|\begin{array}{ccc}
\lambda_{1}^{\prime} & 0 & 0 \\
0 & \lambda_{2}^{\prime} & 0 \\
0 & 0 & \lambda_{3}^{\prime}
\end{array}\right\|=\left\|\begin{array}{ccc}
\lambda_{1} & 0 & 0 \\
0 & \lambda_{2} & 0 \\
0 & 0 & \lambda_{3}
\end{array}\right\|-\left\|\begin{array}{ccc}
E & 0 & 0 \\
0 & E & 0 \\
0 & 0 & E
\end{array}\right\|
$$

where $E=\left(\lambda_{1}+\lambda_{2}+\lambda_{3}\right) / 3$. The most popular decomposition method subdivides the deviatoric moment tensor into the sum of two double couples. Assuming a decreasing ordering in modulus of deviatoric eigenvalues $\left(\left|\lambda_{1}^{\prime}\right|>\left|\lambda_{2}^{\prime}\right|>\left|\lambda_{3}^{\prime}\right|\right)$ we can write

$$
\left\|\begin{array}{ccc}
\lambda_{1}^{\prime} & 0 & 0 \\
0 & \lambda_{2}^{\prime} & 0 \\
0 & 0 & \lambda_{3}^{\prime}
\end{array}\right\|=\left\|\begin{array}{ccc}
M_{0} & 0 & 0 \\
0 & -M_{0} & 0 \\
0 & 0 & 0
\end{array}\right\|+\left\|\begin{array}{ccc}
0 & 0 & 0 \\
0 & M_{1} & 0 \\
0 & 0 & -M_{1}
\end{array}\right\|
$$

where $\left|M_{0}\right|$ and $\left|M_{1}\right|$ are the scalar seismic moment of major and minor double couples respectively.

An alternative method, originally proposed by Knopoff and Randall (1970), decomposes the deviatoric moment tensor into the sum of a double couple and a Compensated Linear Vector Dipole (CLVD), with same $P$ - and $T$-axes. Assuming again a decreasing ordering in modulus for the deviatoric moment tensor eigenvalues, this is given by

$$
\left\|\begin{array}{ccc}
\lambda_{1}^{\prime} & 0 & 0 \\
0 & \lambda_{2}^{\prime} & 0 \\
0 & 0 & \lambda_{3}^{\prime}
\end{array}\right\|=(1-\eta)\left\|\begin{array}{ccc}
\lambda_{1}^{\prime} & 0 & 0 \\
0 & -\lambda_{1}^{\prime} & 0 \\
0 & 0 & 0
\end{array}\right\|+\eta\left\|\begin{array}{ccc}
\lambda_{1}^{\prime} & 0 & 0 \\
0 & -\lambda_{1}^{\prime} / 2 & 0 \\
0 & 0 & -\lambda_{1}^{\prime} / 2
\end{array}\right\|
$$

where $\eta=-2 \lambda_{3}^{\prime} / \lambda_{1}^{\prime}$ is a measure of the size of the CLVD component with respect to the total deviatoric moment tensor. It may range from 0 for a pure double couple to 1 for a pure CLVD. The scalar seismic moment of the double couple is given by $M_{0}=(1-\eta)\left|\lambda_{1}^{\prime}\right|=\left|\lambda_{2}^{\prime}-\lambda_{3}^{\prime}\right|=\left|\lambda_{1}^{\prime}-2 \lambda_{3}^{\prime}\right|$. 
A slightly different procedure is followed by the Harvard CMT and other routine catalogs. They compute the scalar moment $M_{0 b}$ of largest possible (best) double couple that has a CLVD remainder (Dzievonski et al., 1987) as the average of the two largest eigenvalues in modulus

$$
M_{0 b}=\frac{\left|\lambda_{1}^{\prime}\right|+\left|\lambda_{2}^{\prime}\right|}{2}=\frac{\left|\lambda_{1}^{\prime}-\lambda_{2}^{\prime}\right|}{2}
$$

where the last passage is correct because the largest eigenvalue has an opposed sign with respect to the other two due to the zero tensor trace and the assumed eigenvalues ordering. In this representation the isotropic moment tensor decomposes as

$$
\left\|\begin{array}{ccc}
\lambda_{1}^{\prime} & 0 & 0 \\
0 & \lambda_{2}^{\prime} & 0 \\
0 & 0 & \lambda_{3}^{\prime}
\end{array}\right\|=\left\|\begin{array}{ccc}
\left(\lambda_{1}^{\prime}-\lambda_{2}^{\prime}\right) / 2 & 0 & 0 \\
0 & \left(\lambda_{2}^{\prime}-\lambda_{1}^{\prime}\right) / 2 & 0 \\
0 & 0 & 0
\end{array}\right\|+\left\|\begin{array}{ccc}
-\lambda_{3}^{\prime} / 2 & 0 & 0 \\
0 & -\lambda_{3}^{\prime} / 2 & 0 \\
0 & 0 & \lambda_{3}^{\prime}
\end{array}\right\| .
$$

The ratio between the sizes of CLVD remainder and total deviatoric moment tensor is now given by $\eta^{\prime}=$ $=-\lambda_{3}^{\prime} /\left(2 \lambda_{1}^{\prime}\right)$ that is exactly one fourth of the previous definition. Thus equation (A.8) can be written as

$$
\left\|\begin{array}{ccc}
\lambda_{1}^{\prime} & 0 & 0 \\
0 & \lambda_{2}^{\prime} & 0 \\
0 & 0 & \lambda_{3}^{\prime}
\end{array}\right\|=\left(1-\eta^{\prime}\right)\left\|\begin{array}{ccc}
\lambda_{1}^{\prime} & 0 & 0 \\
0 & -\lambda_{1}^{\prime} & 0 \\
0 & 0 & 0
\end{array}\right\|+\eta^{\prime}\left\|\begin{array}{ccc}
\lambda_{1}^{\prime} & 0 & 0 \\
0 & \lambda_{1}^{\prime} & 0 \\
0 & 0 & -2 \lambda_{1}^{\prime}
\end{array}\right\| .
$$

The lower limit of the ratio $\eta^{\prime}=0$ still corresponds to a pure double couple, while the upper one $\eta^{\prime}=0.25$ corresponds to a moment tensor apparently showing a pure CLVD mechanism. However, this decomposition scheme assumes that the double couple component dominates $(75 \%$ of the size of total deviatoric moment tensor).

The latter scheme would be preferable if the CLVD remainder is the result of inversion errors while the previous one (A.6) would be more appropriate if the CLVD component has a physical origin.

\section{REFERENCES}

AKI, K. and P.G. Richards (1980): Quantitative Seismology (W.H. Freeman and Company, San Francisco), pp. 932.

BraunmilleR, J., U. KradolfER and D. Giardini (2002): Regional moment tensor determination in the European-Mediterranean area - initial results, Tectonophysics, 356, 5-22.

Dziewonski, A.M., T.A. Chou and J.H. Woodhouse (1981): Determination of earthquake source parameters from waveform data for studies of global and regional seismicity, J. Geophys. Res., 86, 2,825-2,852.

GASPERINI, P. and G. VANNUCCI (2003): FPSPACK: a package of simple FORTRAN subroutines to manage earthquake focal mechanism data, Comput. Geosci., 29, 893-901.

Julian, B.R., A.D. Miller and G.R. Foulger (1998): Non-double-couple earthquakes, 1. Theory, Rev. Geophys., 36, 525-549. 
KNOPOFF, L. and M.J. RANDALL (1970): The compensated linear vector dipole: a possible mechanism for deep earthquakes, J. Geophys. Res., 75, 4957-4963.

Lay, T. and T.C. Wallace (1995): Modern Global Seismology (Academic Press, San Diego), pp. 521.

Pondrelli, S., A. Morelli, G. Ekström, S. MazZA, E. Boschi and A.M. Dziewonski (2002): European-Mediterranean regional Centroid Moment Tensors Catalog: 1997-2000, Phys. Earth Planet. Int., 130, 71-101.

Pondrelli, S., A. Morelli and G. Ekström (2004): European-Mediterranean regional Centroid Moment Tensor Catalog: solutions for the years 2001 and 2002, Phys. Earth Planet. Int., 145 (1/4), 127-147.

VAnNuCCI, G. and P. GASPERINI (2003): A database of revised fault plane solutions for Italy and surrounding regions, Comput. Geosci., 29, 903-909.

WeSSEL, P. and W.H.F. SMITH (1991): Free software helps map and display data, EOS, Trans. Am. Geophys. Un., 72, 441.

WORKING GROUP (2004): Redazione della mappa di pericolosità sismica prevista dall'Ordinanza PCM del 20 marzo 2003, in Rapporto Conclusivo per il Dipartimento della Protezione Civile, INGV, Milano-Roma, Aprile 2004, pp. $65+5$ appendici.

APPENDIX I. List of directly examined papers (direct references).

Abou Elenean, K.M., H.M. Hussein, A.S. Abu El-Ata and E.I. Ibrahim (2000): Seismological Aspects of the Cairo Earthquake, 12th October 1992, Ann. Geofis., 43 (3), 485-504.

Amorese, D., A. Walker, J.-L. Lagarde, J.-P. Santoire, P. Volant, M. Font and M. Lecornu (2000): New Seismotectonic data from an Intraplate Region: Focal Mechanisms in the Armorican Massif (Northwestern France), Geophys. J. Int., 143, 837-846.

Amoruso, A., L. CRescentini and R. SCARPA (1998): Inversion of source parameters from near- and far-field observations: an application to the 1915 Fucino earthquake, Central Apennines, Italy, $J$. Geophys. Res., 103 (B12), 29989-29999.

AndERSON, H. and J. JACKSON (1987): Active Tectonics of the Adriatic Region, Geophys. J. R. Astron. Soc., 91, 937-983.

Anderson, H. and J. JACKSON (1987): The deep seismicity of the Tyrrhenian Sea, Geophys. J. R. Astron. Soc., 91, 613-637.

Augliera, P., S. Pastore and A. Tomaselli (1990): Sismicità della Lunigiana-Garfagnana: primi risultati di una rete mobile, in Atti GNGTS, $9^{\circ}$ Convegno, Roma, 221-232.

Augliera, P., N. Bethoux, J. Deverchère and C. Eva (1994): The Ligurian Sea: new seismotectonic evidence, Boll. Geofis. Teor. Appl., XXXVI, 363-380.

Azzara, R., A. Basili, L. Beranzoli, C. Chiarabba, R. Di Giovambattista and G. Selvaggi (1993): The seismic sequence of Potenza (May 1990), Ann. Geofis., XXXVI (1), 237-243.

BADAwY, A. (2001): Status of the crustal stress in Egypt as inferred from earthquake focal mechanisms and borehole breakouts, Tectonophysics, 343, 49-61.

BADAWY, A. and A.K.A. FATTAH (2001): Source parameters and fault plane determinations of the 28 December 1999 Northeastern Cairo Earthquakes, Tectonophysics, 343, 63-77.

BAKER, C., J. JACKSON and K. PRIESTley (1993): Earthquakes on the Kazerun Line in the Zagros Mountains of Iran: strike-slip faulting within a fold-and-thrust belt, Geophys. J. Int., 115, 41-61.

Baker, C., D. Hatzfeld, H. Lyon-CAen, E. PApadimitriou and A. Rigo (1997): Earthquake mechanisms of the Adriatic Sea and Western Greece: implications for the oceanic subduction-continental collision transition, Geophys. J. Int., 131, 559-594.

BANGHAR, A.R. and L.R. SyKES (1969): Focal mechanism of earthquakes in the Indian Ocean and adjacent regions, J. Geophys. Res., 74, 632-649. 
Baroux, E., N. BÉthoux and O. Bellier (2001): Analyses of the stress field in Southeastern France from earthquake focal mechanisms, Geophys. J. Int., 145, 336-348.

BASILI, A. and G. VALENSISE (1991): Contributo alla caratterizzazione della sismicità dell'area Marsicano-Fucense, in Aree Sismogenetiche e Rischio Sismico in Italia, edited by E. BoscHI and M. Dragoni (ING, Roma), 197-214.

Basili, A., L. Cantore, M. Cocco, A. Frepoli, L. Margheriti, C. Nostro and G. Selvaggi (1996): The June 12, 1995 microearthquake sequence in the city of Rome, Ann. Geofis., XXXIX (6), $1167-1175$.

Batini, F., M. Caputo, R. Console and R. Rosini (1993): Meccanismo focale di eventi sismici in un campo geotermico, in Atti GNGTS, $12^{\circ}$ Convegno, Roma, 207-216.

Berberian, M., I. Asudeh, R.G. Bilham, C.H. Scholz and C. Soufleris (1979): Mechanism of the main shock and the aftershock study of the Tabas-E-Golshan (Iran) earthquake of September 16, 1978: a preliminary report, Bull. Seismol. Soc. Am., 69 (6), 1851-1859

Berberian, M., J.A. Jackson, M. Qorashi, M.M. Khatib, K. Priestley, M. Talebian and M. GhaFURI-AshtiAni (1999): The 1997 May 10 Zirkuh (Qu'enat) earthquake ( $\left.M_{w} 7.2\right)$ : faulting along the Sistan suture zone of eastern Iran, Geophys. J. Int., 136, 671-694.

Berberian, M., J.A. Jackson, M. Qorashi, M. Telebian, M. Khatib and K. Priestley (2000): The 1994 Sefidabeh Earthquakes in Eastern Iran: Blind Thrusting and Bedding-Plan Slip on a Growing Anticline, and Active Tectonics of the Sistan Suture Zone, Geophys. J. Int., 142, 283-299.

Béthoux, N., J. Fréchet, F. Guyoton, F. Thouvenot, M. Cattaneo, C. Eva, M. Nicolas and M. Granet (1992): A closing Ligurian Sea?, Pure Appl. Geophys., 139, 179-194.

Bezzeghoud, M., A. Ayadi, A. Sebai and H. Benhallou (1994): Seismogenic zone survey by Algerian telemetred seismological network. Case-study of Rouina earthquake, January 19th, 1992 $M=5.2$, Phys. Earth Planet. Int., 84, 235-246.

Bezzeghoud, M., D. Dimitrov, J.C. RuEgG and K. Lammali (1995): Faulting mechanism of the El Asnam (Algeria) 1954 and 1980 earthquakes from modelling of vertical movements, Tectonophysics, 249, 249-266.

Bonasia, V., V. Cagnetti, G. De Natale, F. Pingue and R. Scarpa (1986): Studio dei processi sismotettonici nell' Appennino Centro-Meridionale dall'interpretazione dei dati sismici e di deformazione del suolo, in Atti GNGTS, $5^{\circ}$ Convegno, Roma, 539-566.

BONJER, K.-P. (1997): Seismicity pattern and style of seismic faulting at the eastern border fault of the Southern Rhine Graben, Tectonophysics, 275, 41-69.

Boore, D.M., J.D. Sims, H. Kanamori and S. Harding (1981): The Montenegro, Yugoslavia, earthquake of April 15, 1979: source orientation and strength, Phys. Earth Planet. Int., 27, 133-142.

Bottari, A., P. Capuano, G. De Natale, P. Gasparini, G. Neri, F. Pingue and R. Scarpa (1989): Source parameters of earthquakes in the Strait of Messina, Italy, during this century, Tectonophysics, 166, 221-234.

Bounif, A., H. HAessler and M. Meghraoui (1987): The Constantine (Northeast Algeria) earthquake of October 27, 1985: surface ruptures and aftershock study, Earth Planet. Sci. Lett., 85, 451-460.

Bounif, A., M. Bezzeghoud, L. Dorbath, D. Legrand, A. Deschamps, L. Rivera and H. BenhalLOU (2003): Seismic source study of the 1989, October 29, Chenoua (Algeria) earthquake from aftershocs, broad-band and strong ground motion records, Ann. Geophys., 46 (4), 625-646.

Bowers, D. and R.G. Pearce (1995): Double-couple moment tensor for the 1976 Gazli aftershock earthquake sequence, Tectonophysics, 248, 193-206.

Buforn, E., A. UdíAs and M.A. Colombas (1988): Seismicity, source mechanisms and tectonics of the Azores-Gibraltar Plate Boundary, Tectonophysics, 152, 89-118.

Buforn, E., A. UdíAs and J. MezcuA (1990): Sismicidad y sismotectonica de la region Ibero-Mogrebi, Rev. Geofis., 46, 171-180..

Buforn, E., A. UdíAs and R. MADARIAGA (1991): Intermediate and deep earthquakes in Spain, Pure Appl. Geophys., 136 (4), 375-393. 
Buforn, E., A. Udías, J. Mezcua and R. Madariaga (1991): Deep earthquake under South Spain, 8 March 1990, Bull. Seismol. Soc. Am., 81, 1403-1407.

Buforn, E., C. Sanz De Galdeano and A. Udías (1995): Seismotectonics of the Ibero-Maghrebian region, Tectonophysics, 248, 247-261.

Caccamo, D., G. Neri, A. Sarao and M. Wyss (1996): Estimates of stress directions by inversion of earthquake fault-plane solutions in Sicily, Geophys. J. Int., 125, 857-868.

CANITEZ, N. and B. UÇER (1967): Computer determinations for the fault-plane solutions in and near Anatolia, Tectonophysics, 4 (3), 235-244.

Cattaneo, M., P. Augliera, G. De Luca, A. Gorini, A. Govoni, S. Marcucci, A. Michelini,G. Monachesi, D. Spallarossa, L. Trojani and Xgums (2000): The 1997 Umbria-Marche (Italy) earthquake sequence: analysis of the data recorded by the local and temporary networks, J. Seismol., 4, 401-414.

Chandra, U. (1984): Focal mechanism solutions for earthquakes in Iran, Phys. Earth Planet. Int., 34, 9-16.

Chiodo, G., M.F. Currà, A. Moretti and I. Guerra (1994): Osservazioni sulla sismicità del Mar Ionio Occidentale, in Atti GNGTS, $13^{\circ}$ Convegno, Roma, 915-926.

Chung, W.-Y. and H. KANAmORi (1976): Source process and tectonic implications of the Spanish deep-focus earthquake of march 1954, Phys. Earth. Plan. Int., 13, 85-96.

Ciaccio, M.G., F.R. Cinti, L. Cucci, A. Frepoli, A. Gervasi, L. Margheriti, M.T. Mariucci, P. Montone, S. Pierdominici and S. Pondrelli (2001): Un approccio multidisciplinare per la caratterizzazione delle sorgenti sismogenetiche nelle aree di 'Lacuna Sismica'. Primi risultati per i bacini del Pergola-Melandro e della Val d'Agri., in Atti GNGTS, $20^{\circ}$ Convegno, Roma, 247-248.

CIPAR, J. (1980): Teleseismic observations of the 1976 Friuli, Italy, earthquake sequence, Bull. Seismol. Soc. Am., 70 (4), 963-983.

Cisternas, A., J. Dorel and R. GAUlon (1982): Models of the complex source of the Asnam earthquake, Bull. Seismol. Soc. Am., 72 (6), 2245-2266.

Console, R. (1976): Focal mechanism of some Frioul earthquakes, Boll. Geofis. Teor. Appl., XIX, 69$72 ;$ I, 549-558.

Console, R. and P. FAVAli (1981): Study of the Montenegro earthquake sequence (March-July 1979), Bull. Seismol. Soc. Am., 71 (4), 1233-1248.

Console, R., R. Di Giovambattista, P. Favali and G. Smriglio (1989): Lower Adriatic Sea seismic sequence (January 1986): spatial definition of the seismogenic structure, Tectonophysics, 166, 235-246.

Constantinescu, L., L. Ruprechtova and D. Enescu (1966): Mediterranean-Alpine earthquake mechanism and their seismotectonic implications, Geophys. J. R. Astron. Soc., 10, 347-368.

Deichmann, N., S. PAStore and E. Eva (1991): Meccanismi focali di terremoti delle Alpi ItaloSvizzere, in Atti GNGTS, $10^{\circ}$ Convegno, Roma, 317-329.

De Luca, G., R. Scarpa, L. Filippi, A. Gorini, S. Marcucci, P. Marsan, G. Milana and E. ZamBONELLI (2000): A detailed analysis of two seismic sequences in Abruzzo, Central Apennines, Italy, J. Seismol., 4, 1-21.

Del Ben, A., I. Finetti, A. Rebez and D. Slejko (1991): Seismicity and seismotectonics at the AlpsDinarides contact, Boll. Geofis. Teor. Appl., XXXIII (130/131), 155-175.

Delibasis, N., M. Ziazia, N. Voulgaris, T. Papadoppulos, G. Stavrakakis, D. Papanastassiou and G. Drakatos (1999): Microseismic activity and seismotectonics of Heraklion area (Central Crete Island, Greece), Tectonophysics, 308, 237-248.

Del Pezzo, E., G. De Natale, G. Iannaccone, M. Martini, R. Scarpa and A. Zollo (1985): Analisi preliminare della sequenza sismica dell'Abruzzo mediante i dati di una retesismica digitale, in Atti GNGTS, $4^{\circ}$ Convegno, Roma, 79-96.

DEschamPS, A. and G.C.P. King (1984): Aftershocks of the Campania-Lucania (Italy) earthquake of 23 november 1980, Bull. Seismol. Soc. Am., 74 (6), 2483-2517. 
Deschamps, A., Y. Gaudemer and A. Cisternas (1982): The El Asnam, Algeria, earthquake of 10 october 1980: multiple-source mechanism determined from long-period records, Bull. Seismol. Soc. Am., 72 (4), 1111-1128.

DEWEY, J.W. (1991): The 1954 and 1980 Algerian earthquakes: implications for the characteristic displacement model of fault behaviour, Bull. Seismol. Soc. Am., 81 (2), 446-467.

Di FILIPPO, D. (1950): Sulla rappresentazione in superficie della natura dinamica di una scossa all'ipocentro, Ann. Geofis., III, 263-279.

Ekström, G. and P. England (1989): Seismic strain rates in regions of distributed continental deformation, J. Geophys. Res., 94 (B8), 10231-10257.

EkströM, G., A. Morelli, E. Boschi and A.M. DzIEwonski (1998): Moment tensor analysis of the Central Italy earthquake sequence of september-october 1997, Geophys. Res. Lett., 25 (11), 1971-1974.

El-Sayed, A., R. Arvidsoon and O. KulHANEK (1998): The 1992 Cairo earthquake: a case study of a small destructive event, J. Seismol., 2, 293-302.

Eva, E. and S. PAStORE (1993): Revisione dei meccanismi focali dell'Appennino Settentrionale, in Atti GNGTS, $12^{\circ}$ Convegno, Roma, 147-159.

Eva, E. and S. Solarino (1992): Alcune considerazioni sulla sismotettonica dell'Appennino NordOccidentale ricavate dall'analisi dei meccanismi focali, Studi Geologici Camerti, 2 (special volume), append. crop 1-1a, 75-83.

Eva, E. and S. Solarino (1998): Variations of stress directions in the Western Alpine Arc, Geophys. J. Int., 135, 438-448.

Eva, C., G. Giglia, F. Graziano and F. Merlanti (1978): Seismicity and its relation with surface structures in the North-Western Apennines, Boll. Geofis. Teor. Appl., XX (79), 263-277.

Eva, C., M. Riuscetti and D. Slejko (1988): Seismicity of the Black Sea region, Boll. Geofis. Teor. Appl., XXX (117/118), 53-66.

Eva, E., S. Solarino, C. Eva and G. Neri (1997): Stress tensor orientation derived from fault plane solutions in the Southwestern Alps, J. Geophys. Res., 102, 8171-8185.

EYIDOGAN, H. (1988): Rates of crustal deformation in Western Turkey as deduced from Major Earthquakes, Tectonophysics, 148, 83-92.

EYIDOGAN, H. and J. JACKSON (1985): A seismological study of normal faulting in the Demirci, Alasehir and Gediz earthquakes of the 1969-1970 in Western Turkey: implications for the nature and geometry of deformation in the continental crust, Geophys. J. R. Astron. Soc., 81, 569-607.

Frepoli, A. and A. Amato (1997): Contemporaneous extension and compression in the Northern Apennines from earthquake fault-plane solutions, Geophys. J. Int., 129, 368-388.

FrEPOLI, A. and A. AMATO (2000): Fault plane solutions of crustal earthquakes in Southern Italy (1988-1995): seismotectonic implications, Ann. Geofis., 43 (3), 437-467.

Frepoli, A., G. Selvaggi, C. Chiarabba and A. Amato (1996): State of stress in the Southern Tyrrhenian subduction zone from fault-plane solutions, Geophys. J. Int., 125, 879-891.

Galindo-Zaldivar, J., F. GonZalez-Lodeiro and A. JabAloy (1993): Stress and paleostress in the Betic-Rif Cordilleras (Miocene to Present), Tectonophysics, 227, 105-126.

Gallart, J., M. Daignières, J. Gagnepain-Beyneix and A. Hirn (1985): Relationship between deep structure and seismicity in the Western Pyrenees, Ann. Geophysicae, 3 (2), 239-248.

GAO, L. and T.C. WALLACE (1995): The 1990 Rudbar-Tarom Iranian earthquake sequence: evidence for slip partitioning, J. Geophys. Res., 100 (B8), 15317-15332.

Gasparini, C., G. IANNACCONE, P. SCANDONE and R. SCARPA (1982): Seismotectonics of the Calabrian Arc, Tectonophysics, 84, 267-286.

GASPARINI, C., G. IANNACCONE and R. SCARPA (1985): Fault-plane solutions and seismicity of the Italian Peninsula, Tectonophysics, 117, 59-78.

GiardinI, D. (1984): Systematic analysis of deep seismicity: 200 centroid-moment tensor solutions for earthquakes between 1977 and 1980, Geophys. J. R. Astron. Soc., 77, 883-914. 
Grimison, N.L. and W.-P. CHEN (1986): The Azores-Gibraltar plate boundary: focal mechanisms, depths of earthquakes, and their tectonic implications, J. Geophys. Res., 91 (B2), 2029-2047.

GRIMISON, N.L. and W.-P. CHEN (1988): Source mechanisms of four recent earthquakes along the Azores-Gibraltar plate boundary, Geophys. J. Int., 92, 391-401.

GrÜNThal, G. and D. Stromeyer (1992): The recent crustal stress field in Central Europe: trajectories and finite element modeling, J. Geophys. Res., 97 (B8), 11805-11820.

HatzFeld, D., M. Besnard, K. MaKropoulos and P. Hatzidimitriou (1993): Microearthquake seismicity and fault-plane solutions in the Southern Aegean and its geodynamic implications, Geophys. J. Int., 115, 799-818.

HatzFeld, D., V. Caillot, T.-E. Cherkaoui, H. Jebli and F. Medina (1993): Microearthquake seismicity and fault-plane solutions around the Nékor strike-slip fault, Morocco, Geophys. J. Int., 120, 31-41.

Herak, D., M. Herak, I. Sovic and S. Markusic (1991): Seismicity of Croatia in 1989 and the Kamesnica Mt. Earthquake, Geofizika, 8, 83-99.

HeRAK, M. and M. JUKIC (1993): Fault-plane solution for the earthquake of 25 November 1986 near Knin, Croatia, Geofizika, 10, 61-68.

HeraK, M., D. HERAK and S. MARKUSiC (1995): Fault-plane solutions for earthquake (1956-1995) in Croatia and neighbouring regions, Geofizika, 12, 43-56.

HoRÁLEK, J., J. Š́lEENY̌ and T. FISCHER (2002): Moment tensors of the 1997 earthquake Swarm in Nw Bohemia (Czech Republic): double-couple versus non-double-couple events, Tectonophysics, 356, 65-85.

HuAnG, P.Y and S.C. SAlomon (1987): Centroid depths and mechanisms of mid-ocean ridge earthquakes in the Indian Ocean, Gulf of Aden, and Red Sea, J. Geophys. Res., 92 (B2), 13611382.

HusseIn, H.M. (1999): Source process of the October 12, 1992 earthquake, Ann. Geofis., 42 (4), 665674.

Iannaccone, G., G. Scarcella and R. Scarpa (1985): Terremoti intermedi e profondi del Mar Tirreno. Rilocalizzazione con il metodo Jhd e meccanismi focali, in Atti GNGTS, $4^{\circ}$ Convegno, Roma, 145-157.

IsACKS, B. and P. MOLNAR (1971): Distribution of stresses in the descending lithosphere from a global survey of focal-mechanism solutions of mantle earthquake, Rev. Geophys. Space Phys., 9 (1), 103-124.

Ivancic, I., D. Herak, S. Markusic, I. Sovic and M. HeraK (2001): Seismicity of Croatia in the period 1997-2001, Geofizika, 18-19, 17-29.

JACKSON, J. and T.J. FITCH (1979): Seismotectonic implications of relocated aftershock sequences in Iran and Turkey, Geophys. J. R. Astron. Soc., 57, 209-229.

JACKSON, J. and D. MCKENZIE (1984): Active tectonics of the Alpine-Himalayan Belt between Western Turkey and Pakistan, Geophys. J. R. Astron. Soc., 77, 185-264.

JACKSON, J., J. HAINES and W. HOLT (1992): The horizontal velocity field in the deforming Aegean Sea region determined from the moment tensors of earthquakes, J. Geophys. Res., 97 (B12), 17657-17684.

JACKSON, J., J. HAINES and W. Holt (1995): The Accommodation of Arabia-Eurasia plate convergence in Iran, J. Geophys. Res., 100 (B8), 15205-15219.

Jost, M.J., O. Knabenbauer, J. Cheng and H.-P. Harjes (2002): Fault plane solutions of microearthquakes and small events in the Hellenic Arc, Tectonophysics, 356, 87-114.

KANAMORI, H. and J.W. Given (1981): Use of long-period surface wave for rapid determination of earthquake-source parameters, Phys. Earth. Planet. Int., 27, 8-31.

KANAMORI, H. and J.W. GiVEN (1982): Use of long-period surface wave for rapid determination of earthquake-source parameters, 2. Preliminary determination of source mechanisms of large earthquakes $\left(M_{s} \geq 6.5\right)$ in 1980, Phys. Earth. Planet. Int., 30, 260-268. 
KIM, W.-Y., O. KulHÁNeK and K. MeYer (1984): Source process of the 1981 Gulf of Corinth earthquake sequence from body-wave analysis, Bull. Seismol. Soc. Am., 74 (2), 459-477.

KIRATZI, A.A. and C.A. LANGSTON (1989): Estimation of earthquake source parameters of the May 4, 1972 event of the Hellenic Arc by the inversion of waveform data, Phys. Earth Planet. Int., 57, 225-232.

KIRATZI, A.A. and E. LOUVARI (2001): Source parameters of the Izmit-Bolu 1999 (Turkey) earthquake Sequences from teleseismic data, Ann. Geofis., 44 (1), 33-47.

KIRATZI, A.A. and E. LOUVARI (2003): Focal mechanisms of shallow earthquakes in the Aegean Sea and the surrounding lands determined by waveform modelling: a new database, J. Geodyn., 36, 251-274.

KIRATZi, A.A., G.S. WAGNER and C.A. LANGSTON (1991): Source parameters of some large earthquakes in Northern Aegean determined by body waveform inversion, Pure Appl. Geophys., 135, 515-527.

Koral, H. (2000): Surface rupture and rupture mechanism of the October 1, $1995\left(M_{w}=6.2\right)$ Dinar earthquake, SW Turkey, Tectonophysics, 327, 15-24.

Lammali, K., M. Bezzeghoud, F. Oussadou, D. Dimitrov and H. Benhallou (1997): Postseismic deformation at El Asnam (Algeria) in the seismotectonic context of Northwestern Algeria, Geophys. J. Int., 129, 597-612.

Louvari, E., A.A. Kiratzi and B.C. PAPAZAChos (1999): The Cephalonia transform fault and its extension to Western Lefkada Island (Greece), Tectonophysics, 308, 223-236.

LYNNES, C.S. and L.J. RUFF (1985): Source process and tectonic implications of the great 1975 NorthAtlantic earthquake, Geophys. J. R. Astron. Soc., 82, 497-510.

Lyon-Caen, H., R. Armijo, J. Drakopoulos, J. Baskoutass, N. Delibassis, R. Gaulon, V. Kouskouna, J. Latoussakis, K. Makropoulos, P. Papadimitriou, D. Papanastassiou and G. Pedotti (1988): The 1986 Kalamata (South Peloponnesus) earthquake: detailed study of a normal fault, evidences for east-west extension in the Hellenic Arc, J. Geophys. Res., 93 (B12), 14967-15000.

Maggi, A., J.A. Jackson, K. Priestley and C. Baker (2000): A re-assessment of focal depth distributions in Southern Iran, the Tien Shan and Northern India: do earthquakes really occur in the continental mantle?, Geophys. J. Int., 143, 629-661.

Main, I. G. and P.W. BurTon (1990): Moment-magnitude scaling in the Aegean Area, Tectonophysics, 179, 273-285.

MckenZIE, D. (1972): Active tectonics of the Mediterranean region, Geophys. J. R. Astron. Soc., 30, 109-185.

MCKENZIE, D. (1978): Active tectonics of the Alpine-Himalayan Belt: the Aegean Sea and surrounding regions, Geophys. J. R. Astron. Soc., 55, 217-254.

MedinA, F. (1995): Present-day state of stress in Northern Morocco from focal mechanism analysis, J. Struct. Geol., 17 (7), 1035-1046.

Medina, F. and T.E. Cherkaoui (1992): Mécanismes au foyer des séismes du Maroc et des régions voisinés (1959-1986), conséquences tectoniques, Eclogae Geol. Helv., 85 (2), 433-457.

Meghraoui, M. (1991): Blind reverse faulting system associated with the Mont Chenoua-Tipaza earthquake of 29 October 1989 (North-Central Algeria), Terra Nova, 3 (1), 84-93.

Meghraoui, M., A. Cisternas and H. Philip (1986): Seismotectonics of the lower Cheliff Basin: structural background of El Asnam (Algeria) earthquake, Tectonics, 5 (6), 809-836.

Meghraoui, M., J.L. Morel, J. Andrieux and M. Dahmani (1996): Tectonique Plio-Quaternaire de la Chaine Tello-Rifaine et de la Mer d'Alboran. Une zone complexe de convergence continentcontinent, Bull. Soc. Geol. Fr., 167 (1), 141-157.

Melis, N.S., P.W. Burton and M. Brooks (1995): Coseismic crustal deformation from microseismicity in the Patras area, Western Greece, Geophys. J. Int., 122, 815-836.

Mezcua, J., and J. Rueda (1997): Seismological evidence for a delamination process in the lithosphere under the Alboran Sea, Geophys. J. Int., 129, F1-F8. 
Mezcua, J., E. Buforn, A. UdíAs and J. Rueda (1992): Seismotectonics of the Canary Islands, Tectonophysics, 208, 447-452.

Milano, G., R. Digiovambatista and G. Alessio (1999): Earthquake swarms in the Southern Apennines Chain (Italy): the 1997 seismic sequence in the Sannio-Matese mountains, Tectonophysics, 306, 57-78.

MoreIRA, V.S. (1985): Seismotectonics of portugal and its adjacent area in Atlantic, Tectonophysics, 117, 85-96.

Morelli, A., G. Ekström and M. Olivieri (2000): Source properties of the 1997-1998 Central Italy earthquake sequence from inversion of long-period and broad-band seismograms, J. Seismol., 4, 365-375.

MuçO, B. (1994): Focal mechanism solutions for Albanian earthquakes for the years 1964-1988, Tectonophysics, 231, 311-323.

Nicolas, M., J.P. SANTOIRE and P.Y. DELPECH (1990): Intraplate seismicity: new seismotectonic data in Western Europe, Tectonophysics, 179, 27-53.

Nicolas, M., N. BethouX and B. MadedDU (1998): Instrumental seismicity of the Western Alps: a revised catalogue, Pure Appl. Geophys., 152, 707-731.

Nowroozi, A.A. (1972): Focal mechanism of earthquakes in Persia, Turkey, West Pakistan, and Afghanistan and plate tectonics of the Middle East, Bull. Seismol. Soc. Am., 62 (3), 823-850.

ONCESCU, M.C. (1987): On the stress tensor in Vrancea region, J. Geophys., 62, 62-65.

Oncescu, M.C., C.I. Trifu, T. Hristova, S. Simenova and D. Solakov (1990): A detailed analysis of the Strazhitza (Bulgaria) seismic sequences of 1986: location, focal mechanism and regional stress tensor, Tectonophysics, 172, 121-134.

Ouyed, M., M. Meghroni, A. Cisternas, A. Deschamp, J. Dorel, J. Frechet, R. Gaulon, D. HATZFELD and H. Philip (1981): Seismotectonics of the El Asnam earthquake, Nature, 292, 2631.

OuYed, M., G. Yielding, D. HATZFEld and G.C.P. KING (1983): An aftershock study of the El Asnam (Algeria) earthquake of 1980 October 10, Geophys. J. R. Astron. Soc., 73, 605-639.

PAPAdimitriou, E.E. (1993): Focal mechanism along the convex side of the Hellenic Arc, Boll. Geofis. Teor. Appl., XXXV (140), 401-426.

Papadopoulos, G.A., D.P. Kondopoulou, G.-A. Leventakis and S.B. Pavlides (1986): Seismotectonics of the Aegean region, Tectonophysics, 124, 67-84.

PAPAZACHOS, B.C. and N.D. Delibasis (1969): Tectonic stress field and seismic faulting in the area of Greece, Tectonophysics, 7 (3), 231-255.

Papazachos B.C., D. Mountrakis, A. Psilovikos and G. Leventakis (1979): Surface fault traces and fault plane solutions of the May-June 1978 major shocks in the Thessaloniki area, Greece, Tectonophysics, 53, 171-183.

Papazachos, B.C., D.G. Panagiotopoulos, T.M. Tsapanos, D.M. Mountrakis and G.Ch. DiMOPOULOS (1983): A study of the 1980 summer seismic sequence in the Magnesia region of Central Greece, Geophys. J. R. Astron. Soc., 75, 155-168.

Papazachos, B.C., P.E. Comninakis, E.E. PAPAdimitriou and E.M. Scordilis (1984): Properties of the February-March 1981 seismic sequence in the Alkyonides Gulf of Central Greece, Ann. Geophysicae, 2, 537-544.

Papazachos, B.C., A.A. Kiratzi, Ph. Voimdomatis and Ch.A. Papaioannou (1984): A study of the December 1981-January 1982 seismic activity in Northern Aegean Sea, Boll. Geofis. Teor. Appl., XXVI (101/102), 101-113.

Papazachos, B.C., A.A. Kiratzi, B. Karacostas, D. Panagiotopoulos, E. Scordilis and D.M. MOUNTRAKIS (1988): Surface fault traces, fault plane solution and spatial distribution of the aftershocks of the September 13, 1986 earthquake of Kalamata (Southern Greece), Pure Appl. Geophys., 126, 55-68.

Papazachos, B.C., A.A. Kiratzi and E.E. PApadimitriou (1991): Regional focal mechanisms for earthquakes in the Aegean Area, Pure Appl. Geophys., 136, 405-420. 
Patanè, G., S. Menza, S. Imposa and G. Distefano (1990): Il terremoto Etneo del 29.01.1989: caratteristiche macrosismiche e strumentali, in Atti GNGTS, $9^{\circ}$ Convegno, Roma, 57-65.

Pierri, P., V. Del Gaudio and G. Calcagnile (1993): Meccanismo focale e sismosintesi, in Atti GNGTS, $12^{\circ}$ Convegno, Roma, 227-238.

Pilidou S., Priestley K., Jackson J. and A. MagGi (2004): The 1996 Cyprus earthquake: a large, deep event in the Cyprean Arc, Geophys. J. Int., 1-13, doi: 10.1111/j.1365-246X.2004.02248.

PINO, N.A. and S. MAZZA (2000): The Umbria-Marche (Central Italy) earthquakes: relation between rupture directivity and sequence evolution for the $M_{w}>5$ shocks, J. Seismol., 4, 451-461.

PlenefiSch, T. and K. KLINGE (2003): Temporal variations of focal mechanisms in the Novy Kostel focal zone (Vogtland/NW-Bohemia)-comparison of the swarms of 1994, 1997 and 2000, J. Geodyn., 35, 145-156.

PolONIC, G. (1985): Neotectonic activity at the eastern border of the Pannonian depression and its seismic implications, Tectonophysics, 117, 109-115.

Pondrelli, S., G. Ekström, A. Morelli and S. Primerano (1999): Study of source geometry for tsunamigenic events of the Euro-Mediterranean area, in International Conference on Tsunamis, (UNESCO books, Paris), 297-307.

Pondrelli, S., G. EKSTRÖM and A. Morelli (2001): Seismotectonic re-evaluation of the 1976 Friuli, Italy, seismic sequence, J. Seismol., 5, 73-83.

PRIESTLEY, K., C. BAKER and J. JACKSON (1994): Implications of earthquake focal mechanism data for the active tectonics of the South Caspian Basin and surrounding regions, Geophys. J. Int., 118, 111-141.

RenNer, G. and D. SLeJKo (1986): Studio di alcuni recenti terremoti dell'Italia Nord Orientale in un contesto sismotettonico regionale, in Atti GNGTS, $5^{\circ}$ Convegno, Roma, 577-589.

RENNER, G. and D. SLEJKo (1994): Sismicità strumentali della regione adriatica, in Atti GNGTS, $13^{\circ}$ Convegno, Roma, 907-913.

Renner, G. and D. SLeJko (1994): Some comments on the seismicity of the Adriatic region, Boll. Geofis. Teor. Appl., XXXVI, 141-144.

Renner, G., M.E. Poli and D. Slejko (1991): Il terremoto dell'11 Giugno 1991 nelle Prealpi Carniche Orientali, in Atti GNGTS, $10^{\circ}$ Convegno, Roma, 305-316.

Ribeiro, A., J. Cabral, R. Baptista and L. Matias (1996): Stress pattern in Portugal mainland and the adjacent Atlantic region, West Iberia, Tectonics, 15 (2), 641-659.

RicciARDI, G.P., A. Lo BASCIO and G. LuONGO (1986): L'attività sismica a sciami nell'area Flegrea quale indicatore di intrusione magmatica, in Atti GNGTS, $5^{\circ}$ Convegno, Roma, 503-523.

Rigo, A., H. Lyon-Caen, R. Armijo, A. Deschamps, D. Hatzfeld, K. Makropoulos, P. PapadimitriOU and I. KASSARAS (1996): A microseismic study in the western part of the Gulf of Corinth (Greece): implications for large-scale normal faulting mechanisms, Geophys. J. Int., 126, 663-688.

RocCa, A.CH., G.F. Karakaisis, B.G. Karacostas, A.A. Kiratzi, E.M. Scordilis and B.C. PapaZACHOS (1985): Further evidence on the strike - Slip faulting of the Northern Aegean trough based on properties of the August-November 1983 seismic sequence, Boll. Geofis. Teor. Appl., XXVII (106), 101-108.

Rouland, D. and E. Peterschmitt (1976): On the computation of focal mechanism of Friuli earthquakes, Boll. Geofis. Teor. Appl., XIX, 69-72; I, 889-908.

RuedA, J. and J. MezcuA (2001): Sismicidad, simotectónica y peligrosidad sísmica en Galicia, Istituto Geografico Nacional Madrid, Publicación Técnica No. 35, pp. 64.

Rueda, J. and J. Mezcua (2002): Estudio del terremoto de 23 de septiembre de 2001en Pego (Alicante). Obtención de una relación mbLg-Mw para la Península Ibérica, Rev. Soc. Geol. España, 15 (3/4), 159-173.

Rueda, J., J. Mezcua, E. Buforn and J. Galán (1992): Estudio del terremoto de 13 de septiembre de 1984 en la Sierra Alhamilla (Almería) y su serie de réplicas - Study of the Sierra Alhamilla earthquake of 13 September 1984 and its aftershocks sequency, Rev. Geofis., 48, 87-95. 
SCHICK, R. (1979): A seismotectonic study of the 1908 Messina earthquake, Tectonophysics, 53, 289-290.

Scordilis, E.M., G.F. Karakaisis, B.G. Karacostas, D.G. PAnagiotopoulos, P.E. Comninakis and B.C. PAPAZACHOS (1985): Evidence for transform faulting in the Ionian Sea: the Cephalonia Island earthquake sequence of 1983, Pure Appl. Geophys., 123, 389-397.

SelvagGi, G. (2001): Strain pattern of the Southern Tyrrhenian slab from moment tensors of deep earthquakes: implications on the down-dip velocity, Ann. Geofis., 44 (1), 155-165.

SiPKIN, S.A. and R.E. NeEDHAM (1991): Moment-tensor solutions estimated using optimal filter theory: global seismicity, 1988-1989, Phys. Earth Planet. Int., 67, 221-230.

SLEJKO, D. and A. ReBEZ (1988): Caratteristiche sismotettoniche dell' area Benacense, in Atti GNGTS, $7^{\circ}$ Convegno, Roma, 157-167.

Slejko, D., G.B. Carulli, F. Carraro, D. Castaldini, A. Cavallin, C. Doglioni, V. Iliceto, R. Nicolich, A. Rebez, E. Semenza, A. Zanferrari and C. Zanolla (1987): Modello sismotettonico dell'Italia Nord-Orientale, CNR-GNDT, Rendiconto 1, Trieste, pp. 82.

Slejko, D., G.B. Carulli, R. Nicolich, A. Rebez, A. Zanferrari, A. Cavallin, C. Doglioni, F. Carraro, D. Castaldini, V. Iliceto, E. Semenza and C. Zanolla (1989): Seismotectonics of the Eastern Southern-Alps: a review, Boll. Geofis. Teor. Appl., XXXI (122), 109-136.

Slejko, D., G. Neri, I. Orozova, G. Renner and M. Wyss (1999): Stress field in Friuli (NE Italy) from fault plane solutions of activity following the 1976 main shock, Bull. Seismol. Soc. Am., 89 (4), 1037-1052.

Soufleris, C. and G.S. STEWART (1981): A source study of the Thessaloniki (Northern Greece) 1978 earthquake sequence, Geophys. J. R. Astron. Soc., 67, 343-358.

StANISHKOVA, I. and D. SLEJKO (1990): The 1986 Strazhitza earthquake sequences within the context of the seismicity of Bulgaria, in Atti GNGTS, $9^{\circ}$ Convegno, Roma, 177-188.

STEWARD, G.S. and H. KANAMORI (1982): Complexity of rupture in large strike-slip earthquakes in Turkey, Phys. Earth. Planet. Int., 28, 70-84.

Stich, D., C.J. Ammon and J. Morales (2003): Moment tensor solutions for small and moderate earthquakes in the Ibero-Maghreb region, J. Geophys. Res., 108 (B3), 2148, doi:10.1029/2002JB002057.

Stich, D., J. Batlló, J. Morales, R. Macià and S. Dineva (2003): Source parameters of the 1910 $M_{w}=6.1$ Adra earthquake (Southern Spain), Geophys. J. Int., 155, 539-546.

Sue, C., F. Thouvenot, J. Fréchet and P. Tricart (1999): Widespread extension in the core of the Western Alps revealed by earthquake analysis, J. Geophys. Res., 104 (B11), 25611-25622.

Suleiman, A.S. and D.I. Doser (1995): The seismicity, seismotectonics and earthquake hazard of Lybia, with detailed analysis of the 1935 April 19, $M=7.1$ earthquake sequence, Geophys. J. Int., 120, 312-320.

Sulstarova, E. and S. Kociaj (1980): The Dibra (Albania) earthquake of November 30, 1967, Tectonophysics, 67, 333-343.

Sulstarova, E., V Peç. and P. ShuteriQi (2000): Vlora-Elbasani-Dibra (Albania) transversal fault zone and its seismic activity, J. Seismol., 4, 117-131.

TALEBIAN, M. and J. JACKSON (2004): A reappraisal of earthquake focal mechanisms and active shortening in the Zagros mountains of Iran, Geophys. J. Int., 156 (3), 506-526, doi: 10.1111/j.1365246X.2004.02092.x.

TAYMAZ, T. (1993): The source parameters of the Çubukdag (W Turkey) earthquake of the 1986 October 11, Geophys. J. Int., 113, 260-267.

TAYMAZ, T. and S. PRICE (1992): The 1971 May 12 Burdur earthquake sequence, SW Turkey: a synthesis of seismological and geological observations, Geophys. J. Int., 108, 589-603.

TAYMAZ, T., J. JACKSON and R. WESTAWAY (1990): Earthquake mechanisms in the Hellenic trench near Crete, Geophys. J. Int., 102, 695-731.

TAYMAZ, T., H. EYIDOGAN and J. JACKSON (1991): Source parameters of large earthquakes in the East Anatolian Fault Zone (Turkey), Geophys. J. Int., 106, 537-550. 
TAYMAZ, T., J. JACKSON and D. MCKEnZIe (1991): Active tectonics of the North and Central Aegean Sea, Geophys. J. Int., 106, 433-490.

Thio, H.K., X. Song, C.K. Saikia, D.V. Helmberger and B.B. Woods (1999): Seismic source and structure estimation in the Western Mediterranean using a sparce broadband network, J. Geophys. Res., 104 (B1), 845-861.

Thouvenot, F., J. Fréchet, P. TApponnier, J.-C. Thomas, B. Le Brun, G. Ménard, R. Lacassin, L. Jenatton, J.-R. Grasso, O. Coutant, A. Paul and D. Hatzfeld (1998): The $M_{l} 5.3$ Épagny (French Alps) earthquake of 1996 July 15: a long-awaited event on the Vuache fault, Geophys. J. Int., 135, 876-892.

UDÍAS, A. (1967): The focal mechanism of earthquakes in the southern coast of the Iberian Peninsula, Tectonophysics, 4 (3), 229-234.

Udías A., A. Lopez Arroyo and J. Mezcua (1976): Seismotectonics of the Azores-Alboran region, Tectonophysics, 31, 259-289.

Udías, A., E. Buforn and J. Ruiz De Gauna (1989): Catalogue of Focal Mechanisms of European Earthquakes (Departement of Geophysics, Universidad Complutense, Madrid).

WARD, S.N. and G. VALENSISE (1989): Fault parameters and slip distibution of the 1915 Avezzano, Italy, earthquake derived from geodetic observations, Bull. Seismol. Soc. Am., 79, 690-710.

Westaway, R. (1987): The Campania, Southern Italy, earthquakes of 1962 August 21, Geophys. J. R. Astron. Soc., 88, 1-24.

WESTAWAY, R. and J. JACKSON (1987): The earthquake of 1980 November 23 in Campania-Basilicata (Southern Italy), Geophys. J. R. Astron. Soc., 90, 375-443.

ZANCHI, A. and J. ANGELIER (1993): Seismotectonic of Western Anatolia: regional stress orientation from geophysical and geological data, Tectonophysics, 222, 259-274.

APPENDIX II. List of original papers referred by others (indirect references). As they were not directly examined, some of the mechanisms reported by them may not be included in the database.

Abou Elenean, K. (1993): Seismotectonics of the Mediterranean region north of Egypt and Libya, M.Sc. Thesis (Faculty of Science, Mansoura University, Egypt).

Ahorner, L., H. Murawski and G. SchneIder (1972): Seismotektonische Traverse Von Der Nordsee Bis Zum Apennin, Geol. Rundsch., 61, 915-942.

ANTONINI, M. (1988): Variations of the focal mechanisms of 1985-1986 Western Bohemia swarm events - correlation with spatial distribution of foci and suggested geometry of faulting, in Proceedings of a Workshop on Induced Seismicity and Associated Phenomena, Liblice (Cz. Acc. Sci.), vol. 1, 250-270.

Arvidsson, R., Z. BEN-Avraham, G. EkstrÖm and S. Wdowinski (1998): Plate tectonic framework for the October 9, 1996, Cyprus earthquake, Geophys. Res. Lett., 25 (12), 2241-2244.

BACKER, C. (1993): The active seismicity and tectonics of Iran, Ph.D. Thesis (Univ. of Cambridge, Cambridge, England), pp. 228.

Battacharya, S.N., A.K. Ghose,G. Suresh, P.R. Baidya and R.C. SaXena (1997): Source parameters of Jabalpur earthquake of 22 May 1997, Curr. Sci., 73, 855-863.

Bernard, P., P. Briole, B. Meyer, H. Lyon-Cae, J.M. Gomez, C. Tiberi, C. Berge, R. Cattin, D. HatzFeld, C. Lachet and G. Stavrakakis (1997): A low angle normal fault earthquake: the $M_{s}=6.2$, June, 1995 Aigon earthquake (Greece), J. Seismol., 1, 131-150.

Béthoux, N., M. Cattaneo, P.Y. Delpech, C. Eva and J.P. Rehault (1988): Mécanismes au foyers des séismes en Mer Ligure et dans le Sud des Alpes Occidentales: résultats et interprétation, $C$. R. Acad. Sci. Paris, 307, 71-78. 
Bezzeghoud, M. (1987): Inversion et analyse spectrale des ondes $P$. Potentialité des données numeriques large bande: application à des seismes méditerranées et chiliens, Ph.D. Thesis (Univ. Paris VII, Paris), pp. 225.

Bezzeghoud, M. and E. Buforn (1996): Study of the Alhucemas (26.05.1994) and Mascara (18.08.1994) earthquakes and seismotectonics of the region, Ann. Geophysicae, EGS, the Hague, 6-10 May 1996, Part I, 14, 88.

Bock, G. (2000): Rapid source parameter determination of the August 17, 1999, Izmit earthquake at Gfz Potsdam, Orfeus Newsl., 2 (1).

BORGES, J.F. (1991): Unpublished Report.

Bossolasco, M., G. Cicconi, C. Eva and V. Pasquale (1972): La rete sismica dell'Istituto Geofisico di Genova e primi risultati sulla sismo-tettonica delle Alpi Marittime ed Occidentali, e del Mar Ligure, Riv. Ital. Geofis., XXI, 229-247.

Braunmiller, J. and J. NABELEK (1996): Geometry of continental normal faults: seismological constraints, J. Geophys. Res., 10, 3045-3052.

Buforn, E. (1982): Estudio estadistico de la Direccion de Esfuerzos Principales en Terremotos, Tesis Doctoral (U.C.M.).

BufORN, E. and A. UdíAs (1991): Focal mechanisms of earthquakes in Gulf of Cadiz, South Spain and Alboran Sea, in Seismicity, Seismotectonics and Seismic Risk of the Ibero-Maghrebian Region, edited by J. MeZcuA and A. UdíAS, Istituto Geografico Nacional, Madrid, Sér. Monogr., 8, 29-40.

Buforn, E., M.J. Jimenez and A. UdíAs (1983): Parametros focales de los terremotos de 26 de Mayo de 1975 y 1 de Enero de 1980 en la region Azores-Gibraltar y sismotectonica regional, Rev. Geofis., 39, 51-63.

Buforn, E., J. Mezcua and A. UdíAs (1988): Mecanismo focal del terremoto del Cabo San Vicente de 20 Octubre de 1986, Rev. Geofis., 44, 109-112.

Buforn, E., A. UdíAS and J. MezCuA (1988): Seismicity and Focal Mechanisms in South Spain, Bull. Seism. Soc. Am, 78 (6), 2008-2024.

Burton P., Melis N. and M. Brooks (1995): Coseismic crustal deformationon a fault zone defined by microseismicity inthe Pavliani area, central Greece, Geophys. J. Int., 123, 16-40.

Cagnetti, V., V. Pasquale and S. Polinari (1976): Focal mechanisms of earthquakes in Italy and adjacent regions, Cnen Rt/Amb (76), 4, Roma, pp. 41.

Carreno, E., J. Rueda, C. Lopez-Casado, J. Galan and A. Pelaez (1991): Spanish national strong motion network. Recording of the Huelva earthquake of 20 December 1989, Pure Appl. Geophys., 136, 395-404.

Cello, G., I. Guerra, L. Tortorici, E. Turco and R. Scarpa (1982): Geometry of the neotectonic stress field in Southern Italy: geological and seismological evidence, J. Struct. Geol., 4, 385-393.

Cherkaoui, T.-E. (1988): Fichier des séismes du Maroc et des régions limitrophes 1901-1984, Trav. Inst. Sci., Ser. Géol. Géogr. Phys., 17.

Cherkaoui, T.-E., F. Medina and D. HatzFeld (1991): The Agadir earthquake of February, 29, 1960. Examination of some of the parameters, in Seismicity, Seismotectonics and Seismic Risk of the Ibero-Maghrebian Region, edited by J. MezcuA and A. UdíAS, Istituto Geografico Nacional, Madrid, Sér. Monogr., 8, 133-147.

CocA, P. and E. Buforn (1994): Mecanismos focales en el Sur de Espana: periodo 1965-1985, Estud. Geol. Madrid, 50 (1/2), 33-45.

Costantinescu, L. and D. Encescu (1962): Rev. Géol. Géogr. Acad. R. P. Roum., 6, 157 (in Roumanian).

Costantinescu, L. and D. Encescu (1963): St. Cerc. Geofis. Acad. R. P. Roum., 1, 51 (in Roumanian).

Costantinescu, L. and D. EnCescu (1964): J. Geophys. Res., 69, 667.

CSEM-EMSC (European Mediterranean Seismological Centre), Recent Earthquakes.

Deschamp, A., M. Bezzeghoud and A. Bounif (1991): Seismological study of the Constantine (Algeria) earthquake (27 October 1985), in Seismicity, Seismotectonics and Seismic Risk of the Ibero- 
Maghrebian Region, edited by J. MezcuA and A. UdíAs, Istituto Geografico Nacional, Madrid, Sér. Monogr., 8, 163-173.

Deverchere, J., N. Béthoux, Y. Hello, R. Loaut and C. Eva (1991): Déploiement d'un réseau de sismographes sous-marins et terrestres en Domaine Ligure (Méditerranée): Campagne Sisbalig I, C. R. Acad. Sci. Paris, Ser. Ii, 313, 1023-1030.

Di FilipPo, D. and F. Peronaci (1959): Ann. Geofis., XII, p. 579.

Drakopoulos, J. and N. Delibasis (1982): The focal mechanisms of earthquakes in the major area of Greece for the period 1947-1981, Seismol. Lab. Univ. Athens Publ. 2, 1-72.

DzIEWONSKI, A.M. and J.H. WoOdHOUSE (1983): An experiment in systematic study of global seismicity: centroid-moment tensor solutions for 201 moderate and large earthquakes of 1981, $J$. Geophys. Res., 88, 3247-3271.

DzIEWOnSKI, A.M., A. Friedman and J.H. Woodhouse (1983): Centroid-moment tensor solutions for January-March, 1983, Phys. Earth. Planet. Int., 33, 71-75.

Dziewonski, A.M., A. Friedman, D. Giardini and J.H. Woodhouse (1983): Global seismicity of 1982: centroid-moment tensor solutions for 308 earthquakes, Phys. Earth. Planet. Int., 33, 76-90.

Dziewonski, A.M., J. Franzen and J. Woodhouse (1984): Centroid-moment tensor solutions for July-September, 1983, Phys. Earth. Planet. Int., 34, 1-8.

DZIEWONSKi, A.M., J.E. FrAnZEN and J.H. WoOdhouse (1984): Centroid-moment tensor solutions for October-December 1983, Phys. Earth Planet. Int., 34, 129-136.

DzIEWONSKI, A.M., J.E. FranzEN and J.H. Woodhouse (1984). Centroid-moment tensor solutions for January-March, 1984, Phys. Earth Planet. Int., 34, 209-219.

DziewOnski, A., G. Ekström and M.P. SAlganiK (1995): Centroid-moment tensor solutions for

April-June 1994 (July-September 1994 in preparation), Phys. Earth Planet. Int., 88, 69-78.

EL HADIDY, S. (1993): Source process of the 1992 Cairo, Egypt earthquake using far field seismogram, Report for the Course of Seismology 1992-1993, Iisee, Japan.

ENeSCU, D. (1962): Com. Acad. R. P. Roum., 12, 1279.

ENesCu, D. (1962): Com. Acad. R. P. Roum., 12, 1291.

Enescu, D. and A. Ionescu (1963): Probl. Geofiz. Acad. R. P. Roum., 2, 87 (in Roumanian).

Enescu, D. and D. Jianu (1964): St. Cerc. Geofis. Geogr. Ser. Geofiz. Acad. R. P. Roum., 2,27 (in Roumanian).

EsPINOZA, A.F. and A. LOPEZ-Arroyo (1984): Inconsistencies in the modified Mercally intensities scale, El Asnam, Algeria, earthquake, in Proc. Conf. Int. Sur La Microzonation Sismique, Ech Cheliff, Algeria, 10-12 October 1984, 51-65.

Eyidogan, H. and A. BARKA (1999): The 1 October 1995 Dinar earthquake, SW Turkey, Terra No$v a, 8,479-485$.

FonseCA, J.F.B.D. and R.E. Long (1991): Seismotectonic of SW Iberia: a distributed plate margin?, in Seismicity, Seismotectonics and Seismic Risk of the Ibero-Maghrebian Region, edited by J. Mezcua and A. Udias, Istituto Geografico Nacional, Madrid, Sér. Monogr., 8, 227-240.

FrÉcheT, J. (1978): Sismicité du Sud-Est de la France, une nouvelle méthode de zonage sismique, Thesis $3^{\circ}$ Cycle (Université Grenoble, France), pp. 159.

Fréchet, J. and N. PAVOni (1979): Etude de la Sismicité de la Zone Briançonnaise Entre Pelvoux Et Argentera (Alpes Occidentales) À l'aide d'un Réseau de Stations Portables, Eclogae Geol. Helv., 72 (3), 763-779.

Frepoli, A., G. Selvaggi, C. Chiarabba and A. Amato (1994): Un aiuto alla comprensione della geodinamica del Basso Tirreno: localizzazione e meccanismi focali del periodo 1988-1994, in Atti GNGTS, $13^{\circ}$ Convegno, Roma, 67-82.

FuKAO, Y. (1973): Thrust faulting at a lithospheric plate boundary. The Portugal earthquake of 1969, Earth Planet. Sci. Lett., 18, 205-216.

GangL, G. (1975): Seismotectonic investigations of the western part of the Inner Alpine Pannonia Basin (Eastern Alps and Dinarides), in Proceedings of XIV Gen. Ass. Europ. Seism. Comm., Trieste, 409-410. 
GAO, L., T.C. WALlACE and J.A. JACKSON (1991): Aftershocks of the June 1990 Rudbar-Tarom earthquake: evidence for slip partitioning, EOS Trans., Am. Geophys. Un., 72 (44 Fall Meeting suppl.), p. 335 (abstract).

Giardini, D. and M. Velonì (1988): Una tecnica di correlazione applicata allo studio del campo di sforzo nel basso Tirreno, in Proceedings of the 7th GNGTS-CNR Meeting, Roma, 471480.

Giardini, D., A.M. Dziewonski, J.H. Woodhouse and E. Boschi (1984): Systematic analysis of the seismicity of the mediterranean region using the Centroid-Moment Tensor method, Boll. Geofis. Teor. Appl., 26 (OGS Silver Anniversary vol.), 121-142.

Giardini, D., E. Boschi and B. PALOMBo (1993): Moment tensor inversion from Mednet data regional earthquakes of the Mediterranean, Geophys. Res. Lett., 20, 273-276.

Gibowicz, S.J. and A. Cichowicz (1986): Source parameters and focal mechanism of mining tremors in the Nowa Ruda Coal Mine in Poland, Acta Geophys. Pol., 34 (3), 215-232.

Gibowicz, S.J., B. Guterck, H. Lewandowska-MarciniaK and L. Wysokinski (1982): Seismicity induced by surface mining: the Belchatow, Poland, earthquake of 29 November 1980, Acta Geophys. Pol., 30 (3), 193-219.

Gibowicz, S.J., J. Niewiadomski, P. Wiejacz and B. Domanski (1989): Source study of the Lubin, Poland, mine tremor of 20 June 1987, Acta Geophys. Pol., 37 (2), 111-132.

Girardin, N., D. HatzFeld and R. Guiraud (1977): La sismicité du Nord de l'Algérie, C.R. Somm. Soc. Géol. Fr., 2, 95-100.

Grosser, H. and W. KoHLER (1988): Focal plane solutions of the main eventsduring the earthquake swarm 1985-1986 in Western Bohemia/Vogtland, in Proceedings of a Workshop on Induced Seismicity and Associated Phenomena, Liblice (Cz. Acc. Sci), vol. 2, 49-64.

Guyoton, F. (1991): Sismicité et structure lithospérique des Alpes Occidentales, Thése de Doctorat (Université Grenoble, France), pp. 290.

Hadley, D.M. and H. KanAmori (1975): Seismotectonics of the Eastern Azores-Gibraltar ridge, EOS, Trans. Am. Geophys. Un., 56, p. 1028 (abstract).

HATZFELD, D. (1978): Etude sismotectonique de la zone de collision Ibéro-Maghrébine, Thèse d'Etat (Université Grenoble, France), pp. 281.

HatzFeld, D. and M. Frogneux (1980): Structure and tectonics of the Alboran Sea Area, in Evolution and Tectonics of the Western Mediterranean and Surrounding Areas, edited by A. UDíAS and J. Chanell, Istituto Geografico Nacional, Madrid, 93-108.

Hatzfeld, D., I. Kassaras, D. Panagiotopoulos, D. Amorese, K. Makropoulos, G. Karakaisis and O. CoutANT (1995): Microseismicity and strain pattern in northwestern Greece, Tectonics, 14, 773-785.

HatzFeld, D., D. KementZetzidou, V. Karakostas, M. Ziazia, S. Nothard and P. Bernard (1996): The Galaxidi Earthquake of 18 November 1992: a possible Asperity within the normal fault system of the Gulf of Corinth (Greece), Bull. Seismol. Soc. Am., 86, 1987-1991.

Hodgson, J.H. and J.I. Cock (1956): Direction of faulting in the deep-focus Spanish earthquake of March 29, 1954, Tellus, 8, 321-328.

Hodgson, J.H. and J.I. Cock (1956): Publ. Dom. Obs. Ottawa, 18, p. 149.

Hodgson, J.H. and J.I. Cock (1958): Publ. Dom. Obs. Ottawa, 19, p. 223.

Hodgson, J.H. and A. Stevens (1958): Publ. Dom. Obs. Ottawa, 19, p. 281.

Hordejuk, T. (1957): Acta Geophys. Pol., 5, p. 103 (in Polish).

IAG, The IAG Regional Moment Tensor Project (on line: http://www.ugr.es/ iag/tensor/mtc.html).

Instituto Geografico Nacional (IGN), Madrid, Boletin de Sismos Proximos (on line http://pangea.ign.es/servidor/sismo/cnis/proximo/proximo.html).

Iosif, S., D. Prochazkova and T. Iosif (1979): Seismic source parameters of large earthquakes in Vrancea, Tectonophysics, 53, 195-201.

Iosif, T., M.C. ONCESCU and S. IOSIF (1980): March 4, 1977 Vrancea Earthquake, Spatial Distribu- 
tions of Events and Temporal Evolution of Focal Mechanism (Center for Earth Physics and Seismology, Bucharest).

JACKSON, J.A. and T.J. FITCH (1981): Basement faulting and the focal depth of the larger earthquakes in the Zagros mountains (Iran), Geophys. J. R. Astron. Soc., 64, 561-586.

JACKSON, J. and D.P. MCKENZIE (1988): The relationship between plate motions and seismic moment tensors, and the rates of active deformation in the Mediterranean and Middle East, Geophys. J., 93, 45-73.

Jackson, J., J. Gagnepain, G. Houseman, G. King, P. Papadimitriou, Ch. Soufleris and J. VIRIEUX (1982): Seismicity, normal faulting and geomorphological development of the Gulf of Corinth (Greece): the Corinth earthquakes of February and March 1981, Earth Planet. Sci. Lett., 57, 377-397.

JACKSON, J.A., G. KING and C. ViTA-FinZI (1982): The neotectonics of the Aegean: an Alternative view, Earth Planet. Sci. Lett., 61, 303-318.

JIMENEZ, E. (1991): Focal mechanisms of some European earthquakes from the analysis of single station long-periods record, in Seismicity, Seismotectonics and Seismic Risk of the Ibero-Maghrebian Region, edited by J. MezcuA and A. UdíAs, Istituto Geografico Nacional, Madrid, Sér. Monogr., 8, 87-96.

JimenEZ, M.J. and N. PAVONI (1984): Focal mechanisms of recent earthquakes 1976-1982 and seismotectonics in Switzerland, in Proceedings Session 12, 18th Gen. Ass. Int. Ass. Seism. Phys. Earth. Int. Ak., Postdam, edited by H. STILleR and A. Ritsema, 77-84.

KADINSKY-CADE, K. and M. BARAZANGI (1982): Seismotectonics of southern Iran: the Oman Line, Tectonics, 1, 389-412.

KANAMORI, H. (1981): Seismological Aspects of Intra-Continental Earthquakes (Seismological Laboratory, California Institute of Thecnology, Pasadena, California), 91-125.

KARACOSTAS, B. (1988): Fault plane solutions of the earthquakes of the Aegean and the surrounding area, in Proceedings of the 1st Symposium on the Recent Trends in Seismology and Geophysics, Thessaloniki, July 1-3, pp. 16.

KarapetYan, N.K. (1958): Izv. Acad. Nauk. SSSR, Geophys. Ser., 2, pp. 260 (in Russian).

KIYAK, U. (1987): The investigation of western extension of the North Anatolian Fault, Ph.D. Thesis (Istanbul University, Istanbul), (in Turkish).

KocAeFe, S.S. and G. ATAMAN (1982): Actual tectonics of the Western Anatolia, Yerbilimleri, 9, 149162 (in Turkish).

KonietzKy, H. (1989): Personal Communication.

KulhaneK, O. and K. Meyer (1979): Source parameters of the Volvi-Langadhas earthquake of June 20, 1978 deduced from body-wave spectra at stations Uppsala and Kiruna, Bull. Seismol. Soc. Am., 69, 1289-1294.

KulhaneK, O. and K. Meyer (1983): Spectral Study of the June 20, 1978 Thessaloniki Earthquake, Seismological Section (Uppsala University).

Kunze, T. (1982): Seismotektonische bewegungen in Alpenbereich, Dissertationestelle (Univ. Stuttgart), pp. 167.

LiOTIER, Y. (1989): Modelisation des Ondes de Volume des Séismes de l'Arc Égéen (DEA de l'Université Joseph Fourier, Grenoble, France).

LOPEZ ARroyo, A. and A. UdíAs (1972): Aftershock sequence and focal parameters of the February 28, 1969 earthquake of the Azores-Gibraltar fracture zone, Bull. Seismol. Soc. Am., 62, 699-720.

LouvARI, E. and A. KIRATZI (2001): Source parameters of the September 7, 1999 Athens (Greece) earthquake from teleseismic data (on line: http://www.balkangeophyssoc.org), J. Balkan Geophys. Soc., 43 (3), 51-60.

Louvari, E., A. Kiratzi, B. PAPAZAChos and P. Hatzidimitriou (2001): Fault plane solutions determined by waveform modeling confirm tectonic collision in eastern Adriatic, Pure Appl. Geophys., 158 (9/10), 1613-1638. 
Maamoun, M.E., A. Meghaed, A. Hussin and I. Marzouk (1993): Preliminary studies on Dahshour earthquake, Nat. Res. Inst. Astron. Geophys., Cairo, Egypt, Abstr.

Madeddu, B., N. BÉTHOuX and J.F. STÉPHAN (1996): Champ de contrainte Post-Pliocene et déformations récentes dans les Alpes Sud-Occidentales, Bull. Soc. Géol. Fr., 167, 797-810.

MARTINI, M. and R. SCARPA (1983): Earthquakes in Italym in the last century, in Earthquakes: Observation, Theory and Interpretation, edited by H. KANAMORI (Italian Physical Society, NorthHolland, Amsterdam), 479-487.

Matias (1994): Personal Communication.

Maurer, H., M. Burkhard, N. Deichmann and A.G. Green (1997): Active tectonism in the Western Swiss Alps, Terra Nova, 9, 91-94.

McKenZIE, D.P., Personal Communication.

Medina, F. and T.-E. Cherkaoui (1991): Focal mechanisms of the atlas earthquakes, and their tectonic implications, Geol. Rundsch., 80, 639-648.

MenARD, G. (1988): Structure et cinématique d'une chaine de collision. Les Alpes Occidentales et Centrales, Thesis (Université Joseph Fourier, Grenoble, France).

Mezcua, L. (1985): Esquema sismotectonico del sureste de Espana, in Mecanismo de los Terremotos y Tectonica, edited by A. UdíAs, D. MunOz and E. Buforn (Universidad Complutense, Madrid), 225-232.

Monus, P., L. Tотн and T. Zsiros (1988): Focal mechanism solutions of Central European earthquakes, in XXI Gen. Ass. Europ. Seismol. Comm., Sofia (poster).

MoreIRA, V.S. (1982): Seismotectonics of Portugal and its Adjacent Area in the Atlantic (Instituto Nacional de Meteorologia e Geofisica).

MoreIRA, V.S. (1991): Historical seismicity and seismotectonics of the area situated between the Iberian Peninsula, Morocco, Selvagens and Azores Islands, in Seismicity, Seismotectonics and Seismic Risk of the Ibero-Maghrebian Region, edited by J. MEZcuA and A. UDíAs, Istituto Geografico Nacional, Madrid, Sér. Monogr., 8, 213-225.

NABELEK, J.L. (1984): Determination of earthquake source parameters from inversion of body waves, Ph.D. Thesis (MIT, Cambridge, MA).

NABELEK, J.L. (1985): Geometry and mechanism of faulting of the 1980 El Asnam, Algeria, earthquake from inversion of teleseismic body wave and comparison with field observations, J. Geophys. Res., 90 (B14), 12713-12728.

NAKANISHI, I. and H. KANAMORI (1984): Source mechanisms of twenty-six large, shallow earthquakes $\left(M_{s} \geq 6.5\right)$ during 1980 from $P$-wave first motion and long-period Rayleigh wave data, Bull. Seismol. Soc. Am., 74, 805-818.

NEIC, National Earthquake Information Center (on line http://neic.cr.usgs.gov/), USGS (U.S.A.).

NEIS, US National Earthquake Information Service (on line http://neic.cr.usgs.gov/neis/), USGS (U.S.A.).

NeRI, G. and W. Wyss (1992): Preliminary results from stress tensor inversion of earthquake fault plane solutions in the Southern Tyrrhenian region, Boll. Geofis. Teor. Appl., XXXV, 349-362.

Ni, J. and M. BARAZANGi (1986): Seismotectonic of the Zagros continental collision zone and a comparison with the Himalayas, J. Geophys. Res., 91, 8205-8218.

Ocal, N. (1960): Publ. Dom. Obs. Ottawa, 24, p. 365.

OnCESCU, M.C. and L. ApolOzAn (1984): The earthquake sequence of Rîminicu Sarat, Romania, of 21-22 February 1983, Acta Geophys. Pol., 32, 231-238.

OnCESCU, M.C. and L. ApolozAn (1985): The seismic doublet from Vrancea region of August 1, 1985 (in Roumanian), Stud. Cerc. Geol. Geofiz. Geogr. Geofiz., 24, 12-16.

OnCESCU, M.C. and C.I. TRIFU (1987): A large seismic sequence on April 27-29, 1986 in Vrancea foredeep, Rev. Roum. Géol. Géophys. Géogr. Géophys., 31.

OnCESCU, M.C. and C.J. TRIFU (1987): A large seismic sequence on April 27-29, 1986 in Vrancea Foredeep, Romania, St. Cerc. Stud. Cescetari Geol. Geofiz., 25, 88-97. 
Ouyed, M. (1981): Le tremblement de terre d'El Asnam du 10 Octbre 1980, Etude des Repliques. Thése de Doctorat (Université Grenoble, France).

Panagiotou, M. (2000): Regional stress tensor inversion in Central Greece, M.Sc. Thesis (Aristotle University of Thessaloniki).

PAPAdimitriou, B.C. (1988): Étude de la structure du manteau supérieur del'Europe et modélisation des ondes de volume engendrées par des séismes Égéens, Ph.D. Thesis.

Papadimitriou, E. (1990): Personal Communication.

Papadopoulos, G.A. (1982): Contribution to the study of the active deep tectonics of the Aegean and the surrounding areas, Sci.D. Thesis (University of Thessaloniki), pp. 176 (in Greek with English abstract).

PaPAZACHOS, B.C. (1975): Seismic activity along the Saronikos-Corinth-Patras gulfs, Bull. Nat. Obs. Athens.

Papazachos, B.C., D. Mountrakis, A. Psilovikos and G. Leventakis (1980): Focal properties of the 1978 earthquakes in the Thessaloniki area, Bulg. Geophys. J., 6, 72-80.

Papazachos, B.C., A.A. Kiratzi, P.M. Hatzidimitriou and A.C. RocCA (1984): Seismic faults in the Aegean area, Tectonophysics, 106, 71-85.

PARKe, G. (2001): Active tectonic and sedimentary processes in Western Turkey, Ph.D. Thesis (University of Cambridge).

PDE, Monthly Listings (on line: http://neic.usgs.gov/neis/data_services/ftp_files.html), USGS (U.S.A.).

PinAR, A. (1998): Source inversion of the October 1, 1995, Dinar earthquake $M_{s}=6.1$. A rupture model with implications for seismotectonics in SW Turkey, Tectonophysics, 292, 255-266.

Pospisil, L., V. SchENK and Z. SchenKovA (1985): Relation between seismoactive zones and remote sensing data in the West Carpathians, in Proceedings of 3rd International Symposium on the Analysis of Seismicity and Seismic Risk, Liblice Castle (Cz. Acc. Sci.), vol. 1, 356-263.

Prochazkova, D. (1979): Determination of source parameters of some European earthquakes on the basis of records of seismic station Kasperske Hory, Travaux Geophys., XXVII.

Prochazkova, D. (1980): Determination of Source Parameters (Geophysical Institute, Czechoslovak Academy of Science, Prague).

Prochazkova, D. (1983): Source parameters of several earthquakes recorded at the seismic station Kasperske Hory, Acta Geodaet. Geophys. Montanist. Hung., 18, 83-96.

Purcaru, G. and H. Berckhemer (1984): Quantitative relations of seismic source parameters and classification of earthquakes, Tectonophysics, 84, 57-128.

RADU, C. (1976): The tectonic stress and tectonic motion direction in Romania, in Proceedings of Seminar on Seismic Zoning Maps, Skopje, vol. 1, 84-100.

RADU, C. and M.C. ONCESCU (1980): Focal Mechanism of Roumanian earthquakes and their correlation with tectonics, I. Catalogue of fault plane solutions, Report CFPS/CSEN 30.78.1 (in Roumanian).

RADU, C. and M.C. ONCESCU (1982): A note on thedeep Vrancea earthquake of May 16, 1982, $R e$ port CFPS/CSEN 30.81 .8 (in Roumanian).

RADU, C. and M.C. ONCESCU (1987): Focal process of August 30, 1986 Vrancea earthquake, Report CFPS/CSEN 30.86 .3 (in Roumanian).

RADU, C., E. CRISAN and M.C. ONCESCU (1981): Fault plane solutions of Roumanian earthquakes occurred in 1981, Report CFPS/CSEN 30.81 .8 (in Roumanian).

RÄKERS, E. and G. MüLLER (1982): The Roumanian earthquake of March 4, 1977, III. Improved focal model and moment determination, J. Geophys., 50, 143-150.

ReAsenberg, P. and D. OpPenheimer (1985): Fpfit, Fpplot and Fppage: Fortran computer programs for calculating and displaying earthquake fault plane solutions, U.S. Geol. Surv. Open File Rep. 85-739, pp. 109.

Ritsema, A. (1974): The earthquake mechanisms of the Balkan region, R. Netherl. Meteorol. Inst., 
De Bilt, Sci. Rep. 74-4, 1-36.

RiusCetTI, M. and R. SchicK (1975): Earthquakes and tectonics in Southern Italy, Boll. Geofis., 17, 59-78.

Rueda, J., J. Mezcua and M. Sanchez Ramos (1996): La serie sismica de Adra (Almeria) de 19931994 y sus principales consequencias seismotectonicas, Avan. Geofis. Geod., 1, 91-98.

SCHÄFFNER, H.J. (1959): Die Grundlagen und Auswerteverfahren Zur Seismischen Bestimmung Von Erdebeben Mechanismen, Freiberger Forschungshefte C63 Geophysik, Akademie Verlang Berlin.

SCHÄFFNER, H.J. (1959): Tabelle kinematischer Erdebebenherdparameter, Veröffentl No. 115 (Inst. Angew. Geophys. Freiberg).

Schmedes, E. (1984): Bayerische Molasse, in Erdbeden in der Bundesrepublik Deutschland 1981 (Bundesanstalt fur Geowissenschaften und Rohstoffe, Hannover), pp. 25-26,

Schmedes, E. (1987): Alpen und Molasse, in Erdbeden in der Bundesrepublik Deutschland 1982, (Bundesanstalt fur Geowissenschaften und Rohstoffe, Hannover), pp. 45.

SchneIDER, G. (1967): Erdbeden und Tektonik in Sudwest-Deutschland, Tectonophysics, 5, 459-511.

SHIROKOVA, E.I. (1966): Personal Communication.

SHIROKOVA, E.I. (1967): General features in the orientation of principal stresses in earthquake foci in the Mediterranean Asian seismic belt, Izv. Earth Phys., 1, 12-22.

SHIROKOVA, E.I. (1972): Stress pattern and probable motion in the earthquake foci of the AsiaMediterranean seismic belt, in Elastic Strain Field of the Earth and Mechanisms of Earthquake Sources, edited by L. M. BALAKINA et al. (Nauka, Moscow), 8.

SLEJKO, D. and G. RENNER (1984): La sequenza sismica iniziata col terremoto del 6 Maggio 1976 in Friuli, in Finalità ed Esperienze della Rete Sismometrica del Friuli-Venezia Giulia (Reg. Auton. Friuli-Venezia Giulia, Trieste), 75-91.

Sulstarova, E. (1986): The seismicity of Albania, Ms. Thesis (Seismological Center, Tirana, Albania), pp. 230 (in Albanian).

Thio, H.K., K. Satake, M. KiKuchi and H. Kanamori (1990): On the Sudan, Iran and Philippines earthquakes of 1990, EOS, Trans., Am. Geophys. Un., 71, 1438 (abstract).

Thouvenot, F. (1996): Aspects géophysiques et structuraux des Alpes Occidentales et de trois autres orogènes: Atlas, Pyrénées, Oural, Thesis (Université Joseph Fourier, Grenoble, France).

UdíAs, A. and A. LoPEZ ARROYo (1970): Body and surface wave study of source parameters of the March 15, 1964 Spanish earthquake, Tectonophysics, 9, 323-346.

US Geological SuRvey (1984): Preliminary Determination of Epicenters, Monthly Listing, US Department of the Interior, Geological Survey, January 1983.

US Geological Survey (1984): Preliminary Determination of Epicenters, Monthly Listing, US Department of the Interior, Geological Survey, October 1983.

VIDAL, F. (1986): Sismotectonica de la region Beticas-Mar de Alboran, Thesis (University of Granada), pp. 450.

Volant, P., C. Berge-Thierry, P. Dervin, M. Cushing, G. Mohammadioun and F. Mathieu (2000): The south eastern durance fault permanent network: preliminary results, J. Seismol., 4, 175-189.

Vvedenskaya, A.V. and L. Ruprechtová (1958): Izv. Acad. Nauk. SSSR, Geophys. Ser, 3, 277 (in Russian).

VvedENSKAYA, A.V. and L. RuPREChtovÁ (1961): Characteristic features of stress distribution in the foci of earthquakes at the bend of the Carpathian arc, Izv. Acad. Nauk. SSSR, Geophys. Ser., 7, 953-965 (in Russian).

WALKer, R. (2003): Active faulting and tectonics of eastern Iran, Ph.D. Thesis (University of Cambridge), pp. 204.

WiCKENS, A.J. and J.H. Hodgson (1967): Computer Re-evalutation of Earthquake Mechanism Solutions (Departement of Energy, Mines and Resources, Ottawa).

Won-Young, K., O. KulHANEK and K. MeYer (1984): Source processes of the 1981 Gulf of Corinth 
earthquake sequence from body-wave analysis, Bull. Seismol. Soc. Am., 74, 459-477.

Wright, T.J., B.E. Parsons, J. Jackson, M. Haynes, E. Fielding, P. England and P. Clarke (1999): Source parameters of the 1 October 1995 Dinar (Turkey) earthquake frorm SAR interferometry and seismic body modelling, Earth Planet. Sci. Lett., 172, 23-37.

YIELDING, G. (1985): Control of rupture by fault geometry during the 1980 El Asnam (Algeria) earthquake, Geophys. J. R. Astron. Soc., 81, 641-670.

YilmAZTURK, A. and P.W. BuRTON (1999): Earthquake source parameters as inferred from body waveform modeling, southern Turkey, J. Geodyn., 27, 469-499.

ZAhrADNIK, J., V. VAVRYCUK, J. JANSKY and J. ZEDNIK (1988): Focal mechanisms of selected events of West Bohemia earthquake swarm 1985-1986 constrained by $P$-wave amplitudes, in Proceedings of Workshop on Induced Seismicity and Associated Phenomena, Liblice (Cz. Acc. Sci), 271289. 